Article

\title{
Genesis and Evolution of Ferromanganese Crusts from the Summit of Rio Grande Rise, Southwest Atlantic Ocean
}

\author{
Mariana Benites ${ }^{1, *}$, James R. Hein ${ }^{2} \mathbb{D}$, Kira Mizell ${ }^{2} \mathbb{D}$, Terrence Blackburn ${ }^{3}$ and Luigi Jovane ${ }^{1} \mathbb{D}$ \\ 1 Institute of Oceanography, University of São Paulo, Praça do Oceanográfico 191, 05508-120 São Paulo, SP, \\ Brazil; jovane@usp.br \\ 2 U.S. Geological Survey, PCMSC, 2885 Mission St., Santa Cruz, CA 95060, USA; jhein@usgs.gov (J.R.H.); \\ kmizell@usgs.gov (K.M.) \\ 3 Department of Earth Sciences, University of California, Santa Cruz, 1156 High Street EMS A108, Santa Cruz, \\ CA 95064, USA; terryb@ucsc.edu \\ * Correspondence: mariana.benites@usp.br; Tel.: +55-11-3091-6609
}

Received: 23 February 2020; Accepted: 10 April 2020; Published: 14 April 2020

\begin{abstract}
The Rio Grande Rise (RGR) is a large elevation in the Atlantic Ocean and known to host potential mineral resources of ferromanganese crusts (Fe-Mn), but no investigation into their general characteristics have been made in detail. Here, we investigate the chemical and mineralogical composition, growth rates and ages of initiation, and phosphatization of relatively shallow-water (650-825 m) Fe-Mn crusts dredged from the summit of RGR by using computed tomography, X-ray diffraction, ${ }^{87} \mathrm{Sr} /{ }^{86} \mathrm{Sr}$ ratios, U-Th isotopes, and various analytical techniques to determine their chemical composition. Fe-Mn crusts from RGR have two distinct generations. The older one has an estimated age of initiation around 48-55 Ma and was extensively affected by post-depositional processes under suboxic conditions resulting in phosphatization during the Miocene (from 20 to 6.8 Ma). As a result, the older generation shows characteristics of diagenetic Fe-Mn deposits, such as low $\mathrm{Fe} / \mathrm{Mn}$ ratios (mean 0.52), high $\mathrm{Mn}, \mathrm{Ni}$, and Li contents and the presence of a $10 \AA$ phyllomanganate, combined with the highest $\mathrm{P}$ content among crusts (up to $7.7 \mathrm{wt} \%$ ). The younger generation is typical of hydrogenetic crusts formed under oxic conditions, with a mean $\mathrm{Fe} / \mathrm{Mn}$ ratio of 0.75 and mean $\mathrm{Co}$ content of $0.66 \mathrm{wt} \%$, and has the highest mean contents of $\mathrm{Bi}, \mathrm{Nb}, \mathrm{Ni}, \mathrm{Te}, \mathrm{Rh}, \mathrm{Ru}$, and $\mathrm{Pt}$ among crusts formed elsewhere. The regeneration of nutrients from local biological productivity in the water column is the main source of metals to crusts, providing mainly metals that regenerate rapidly in the water column and are made available at relatively shallow water depths $(\mathrm{Ni}, \mathrm{As}, \mathrm{V}$, and $\mathrm{Cd})$, at the expense of metals of slower regeneration ( $\mathrm{Si}$ and $\mathrm{Cu}$ ). Additionally, important contributions of nutrients may derive from various water masses, especially the South Atlantic Mode Water and Antarctic Intermediate Water (AAIW). Bulk Fe-Mn crusts from the summit of RGR plateau are generally depleted in metals considered of greatest economic interest in crusts like $\mathrm{Co}, \mathrm{REE}, \mathrm{Mo}, \mathrm{Te}$, and $\mathrm{Zr}$, but are the most enriched in the critical metals $\mathrm{Ni}$ and Li compared to other crusts. Further investigations are warranted on Fe-Mn crusts from deeper-water depths along the RGR plateau and surrounding areas, which would less likely be affected by phosphatization.
\end{abstract}

Keywords: ferromanganese crusts; phosphatization; Rio Grande Rise; critical metals

\section{Introduction}

Ferromanganese (Fe-Mn) crusts are ubiquitous chemical sedimentary rocks occurring on oceanic elevations (ridges, seamounts, and guyots) formed by the precipitation of Fe oxyhydroxide and Mn oxide directly from seawater onto a hard surface [1]. This process is called hydrogenesis and is remarkably 
slow, resulting in crust growth rates typically on the order of 1-5 mm/Myr [2]. During formation, crusts take up and concentrate critical metals from seawater (e.g., $\mathrm{Co}, \mathrm{Ni}, \mathrm{Cu}, \mathrm{Te}, \mathrm{Pt}, \mathrm{Zr}, \mathrm{Nb}, \mathrm{W}, \mathrm{Bi}, \mathrm{La}, \mathrm{Ce}, \mathrm{Nd}$, $\mathrm{Eu}$, and $\mathrm{Tb}$ ) in substantial concentrations relative to their ocean-water concentrations. Economic deposits of many of these critical elements, such as metals crucial for high-tech and green-tech applications, that may undergo sporadic shortages [3], and may be rare on the continents [4-6]. In particular, $\mathrm{Co}, \mathrm{Te}, \mathrm{Bi}$, and many heavy rare earth elements (REE) plus yttrium (HREY) are more enriched in Fe-Mn crusts compared to most land-based mineral deposits. For these reasons, interest in mining Fe-Mn deposits from the ocean floor has intensified.

Since Fe-Mn crusts form by chemical precipitation at slow rates, the study of crust layers provides valuable information about the evolution of the past ocean [2]. However, large areas of Fe-Mn crust deposits in the global ocean remain unexplored, and the Rio Grande Rise (RGR) in the Southwest Atlantic Ocean is one of those areas.

Fe-Mn crust deposits have been moderately well studied in the so-called prime crust zone (PCZ) in the Northwest Pacific Ocean (defined by [7]), where crusts have the highest metal contents and tonnages [1] due to their growth on the oldest seamounts in the global ocean. Crust deposits from elsewhere are typically described in comparison to PCZ crusts. The Atlantic Ocean is a much younger ocean basin with fewer volcanic edifices for crust growth; however, Fe-Mn crust from seamounts in the NE Atlantic around the Madeira, Canary, and Azores islands have been moderately well-studied. These NE Atlantic deposits show characteristics similar to those of hydrogenetic crusts adjacent to continental margins as they have lower contents of Mn-phase elements, $\mathrm{Mn}, \mathrm{Co}, \mathrm{Ni}, \mathrm{Zn}$, and $\mathrm{Cu}$ and higher terrigenous input as exemplified by relatively higher $\mathrm{Fe}, \mathrm{Pb}, \mathrm{Al}$, $\mathrm{Si}$, and $\mathrm{Th}$ contents than open-ocean crusts [8-11]. In the Canary Island Seamount Province, crusts can be thick (maximum $250 \mathrm{~mm}$ ) and may be as old as $76 \mathrm{Ma}$ [11]. On Tropic seamount, crusts ages average $10 \mathrm{Ma}$ and growth rates are higher than for PCZ crusts, and phosphatization of Tropic Seamount crusts is not as pronounced as in crusts from the PCZ [8]. Here, we use "Ma" for millions of years ago and "Myr" for a time interval of millions of years.

Typical black to dark-grey hydrogenetic Fe-Mn crusts were found on São Paulo Ridge at $2871 \mathrm{~m}$ depth, which is close to RGR; those crusts started growing $30 \mathrm{Ma}$ with growth rates of $0.5-3 \mathrm{~mm} / \mathrm{Myr}$ and show no evidence of growth hiatuses or influence of phosphatization [12]. In addition, one pebble coated by Fe-Mn lamina of hydrogenetic origin was studied [13]. Comparison of RGR crusts with the distant NE Atlantic Fe-Mn crusts in addition to the nearby São Paulo Ridge provides valuable information regarding the varying oceanographic conditions throughout the Atlantic Ocean and also provides insight into which regions should be prioritized for economic exploration.

Knowledge about the environment of RGR is scarce and even baseline information needed for potential future mining activities is not available [14], especially concerning the extent of mineral deposits, the main sediment and rock types, small-scale morphology, and ecosystems. Here, we explore mineralogical, geochemical, and isotopic characteristics of Fe-Mn crusts from the summit area of RGR. We evaluate their content of critical metals and controls on metal enrichments. We also investigate the history of crust formation and phosphatization of the crusts.

\section{Study Area}

RGR is located about $1000 \mathrm{~km}$ east of the Brazilian coast and $2000 \mathrm{~km}$ west of the Mid Atlantic Ridge (MAR) and is composed of the Western Rio Grande Rise (WRGR) and the Eastern Rio Grande Rise (ERGR; Figure 1). RGR is one of the largest oceanic elevations in the South Atlantic Ocean, rising to up to $500 \mathrm{~m}$ water depth, and is surrounded by abyssal plains $4000 \mathrm{~m}$-deep. These high elevations separate the Brazil Basin (BB) to the north and the Argentine Basin (AB) to the south. The Vema Channel isolates the WRGR from the continental shelf. An NW-SE trending 10 to $20 \mathrm{~km}$-wide and $1000 \mathrm{~m}$-deep valley cuts through the center of the entire RGR, which may correspond to an accommodation zone resulting from extension in the region [15]. The central valley provides an extremely steep slope up to the rim of RGR plateau, which is an area where Fe-Mn crusts are likely to form due to lower sedimentation on the slope as well as exposed rock surfaces [14]. 

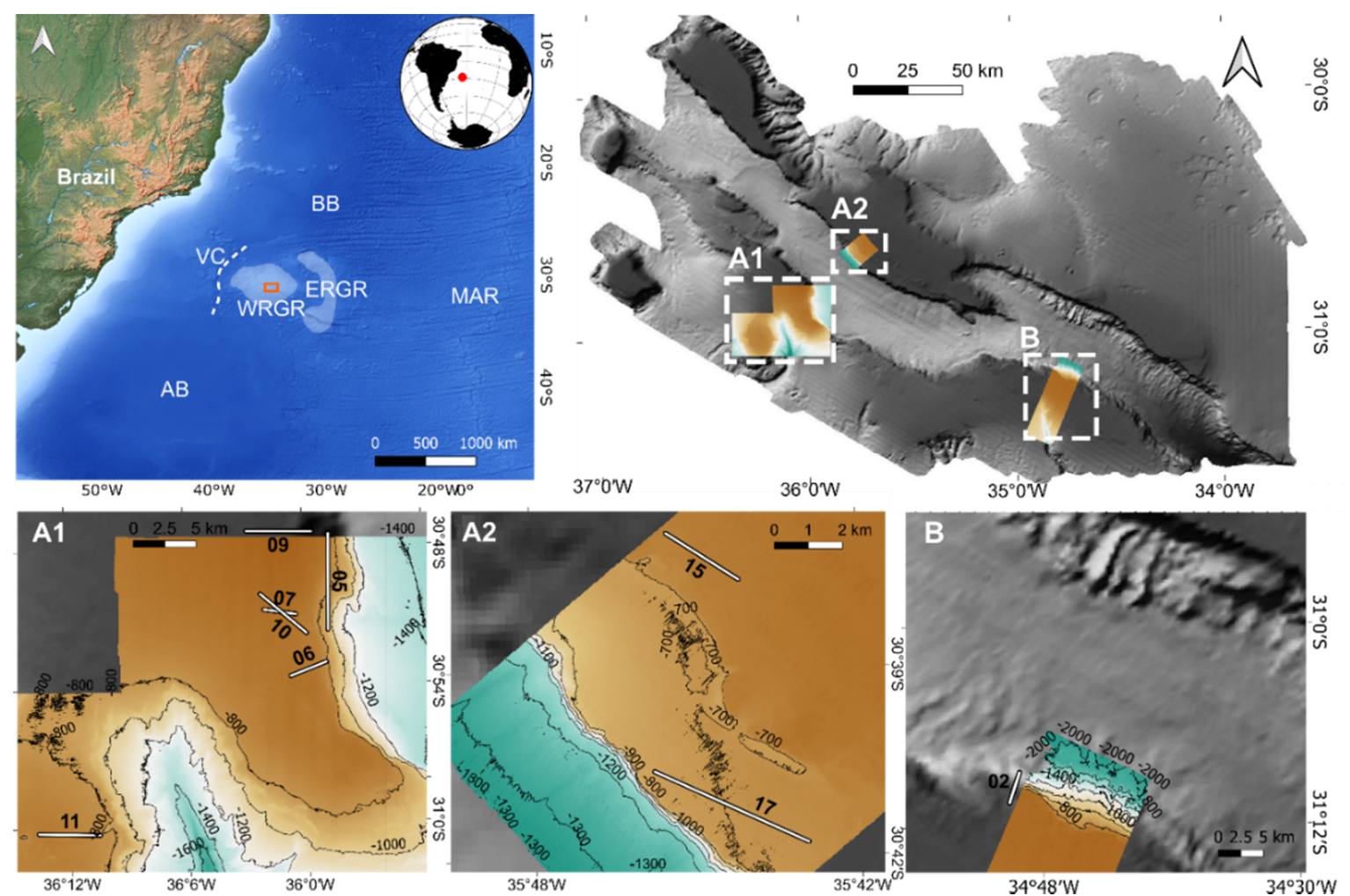

Figure 1. (Upper left) Location map with main morphological features comprising the southwest Atlantic Ocean. $\mathrm{AB}=$ Argentine Basin; $\mathrm{BB}=$ Brazilian Basin; $\mathrm{MAR}=$ Mid-Atlantic Ridge; WRGR = Western Rio Grande Rise; ERGR = Eastern Rio Grande Rise; VC = Vema Channel. The orange square corresponds to the map in the upper right, which shows the surveyed areas A1, A2, and B. (Lower right to left) location of dredges (white lines) in each surveyed area.

Although the formation of RGR is not fully understood, some agreement exists among studies that RGR and Walvis Ridge in the southeast Atlantic formed together as a single ridge on the MAR during the Coniacian/Santonian (85 Myr; [16]). The two ridges then separated and drifted apart due to seafloor spreading. After cooling and thermal subsidence of the oceanic crust, the rise received pelagic sediments [17], until another volcanic event affected the RGR about $46 \mathrm{Myr}$ ago during the Eocene [16]. This volcanic activity uplifted RGR and created several volcanic islands and seamounts. On the islands, volcanism generated pyroclastic debris that was deposited across the platform by turbidity currents. Once the volcanic activity ceased, thermal subsidence again took place and the islands were eroded and leveled by waves and currents as they subsided, creating the flat-topped edifice (guyot) characteristic of RGR's highest elevations of today. Since then, accumulation of pelagic sediment composed mainly by nannofossils and planktonic foraminifera with a small amount of terrigenous components has been the dominant sedimentation processes along RGR [18].

The Ce anomaly of carbonate sediments suggests that anoxic ocean-water conditions prevailed on RGR until the Maastrichtian (70 Myr), followed by increasing oxygenation during the early Eocene (70-55 Myr), when it reached redox conditions similar to modern conditions [19], and possibly the conditions that allowed the Fe and Mn (oxyhydr)oxides to accumulate. This shift is associated with the RGR-Walvis Ridge subsidence and extensional creation of the north-south deep-water passage, which improved deep-water circulation [20].

Currents around RGR are strong (up to $50 \mathrm{~cm} \cdot \mathrm{s}^{-1}$ ) but variable due to tidal effects [21]. The horizontal current velocity at the seabed is enhanced along the shallower areas of the RGR main plateau [14], which may promote $\mathrm{Fe}-\mathrm{Mn}$ crust erosion. 


\section{Samples and Methods}

\subsection{Samples}

Twenty-two Fe-Mn crusts were used in this work, dredged during a multidisciplinary expedition (RGR1) to the summit of WRGR on board the research vessel Alpha Crucis (Instituto Oceanográfico, Universidade de São Paulo, Brazil), from 30 January to 20 February 2018 (Figure 1; [22]). The dredge location and water depth (Table 1 ) were taken as averages between dredge on-bottom and off-bottom positions. The rock samples were rinsed with fresh water on board ship during cutting.

Table 1. List of samples and locations ${ }^{1}$.

\begin{tabular}{|c|c|c|c|c|c|c|c|c|c|}
\hline \multirow{2}{*}{$\begin{array}{c}\text { Sample ID }^{2} \\
\text { RGR1_D02_022 }\end{array}$} & \multicolumn{3}{|c|}{ Latitude } & \multicolumn{3}{|c|}{ Longitude } & \multirow{2}{*}{$\begin{array}{c}\text { Depth (m) } \\
825.5\end{array}$} & \multirow{2}{*}{$\begin{array}{c}\text { Area } \\
B\end{array}$} & \multirow{2}{*}{$\begin{array}{c}\text { Morphology } \\
\text { slope }\end{array}$} \\
\hline & 31 & 9.351 & $S$ & 34 & 49.804 & W & & & \\
\hline RGR1_D02_030 & 31 & 9.351 & $S$ & 34 & 49.804 & W & 825.5 & B & slope \\
\hline RGR1_D02_039 & 31 & 9.351 & $S$ & 34 & 49.804 & W & 825.5 & B & slope \\
\hline RGR1_D05_011 & 30 & 53.367 & S & 35 & 58.854 & W & 739.0 & A1 & plateau \\
\hline RGR1_D05_016 & 30 & 53.367 & S & 35 & 58.854 & W & 739.0 & $\mathrm{~A} 1$ & plateau \\
\hline RGR1_D06_003 & 30 & 53.634 & S & 35 & 59.933 & W & 716.5 & A1 & plateau \\
\hline RGR1_D06_013 & 30 & 53.634 & S & 35 & 59.933 & W & 716.5 & A1 & plateau \\
\hline RGR1_D07_002 & 30 & 51.136 & S & 36 & 1.319 & W & 684.0 & A1 & plateau \\
\hline RGR1_D07_003 & 30 & 51.136 & S & 36 & 1.319 & W & 684.0 & A1 & plateau \\
\hline RGR1_D07_005 & 30 & 51.136 & $S$ & 36 & 1.319 & W & 684.0 & A1 & plateau \\
\hline RGR1_D07_009 & 30 & 51.136 & S & 36 & 1.319 & W & 684.0 & A1 & plateau \\
\hline RGR1_D07_020 & 30 & 51.136 & S & 36 & 1.319 & W & 684.0 & $\mathrm{~A} 1$ & plateau \\
\hline RGR1_D09_001 & 30 & 47.638 & $S$ & 36 & 1.398 & W & 650.5 & A1 & plateau \\
\hline RGR1_D09_002 & 30 & 47.638 & $S$ & 36 & 1.398 & W & 650.5 & A1 & plateau \\
\hline RGR1_D09_003 & 30 & 47.638 & $S$ & 36 & 1.398 & W & 650.5 & A1 & plateau \\
\hline RGR1_D10_002 & 30 & 51.205 & $S$ & 36 & 1.146 & W & 686.5 & A1 & plateau \\
\hline RGR1_D10_003 & 30 & 51.205 & $S$ & 36 & 1.146 & W & 686.5 & A1 & plateau \\
\hline RGR1_D11_003 & 31 & 0.5395 & $S$ & 36 & 12.495 & W & 751.0 & A1 & plateau \\
\hline RGR1_D11_004 & 31 & 0.5395 & S & 36 & 12.495 & W & 751.0 & A1 & plateau \\
\hline RGR1_D15_017 & 30 & 37.518 & S & 35 & 45.712 & W & 648.0 & $\mathrm{~A} 2$ & plateau \\
\hline RGR1_D17_016 & 30 & 41.499 & S & 35 & 44.508 & W & 697.0 & A2 & plateau \\
\hline RGR1_D17_017 & 30 & 41.499 & $S$ & 35 & 44.508 & W & 697.0 & A2 & plateau \\
\hline
\end{tabular}

${ }^{1}$ Latitude, longitude, and water depths are mean values for dredge on-bottom and off-bottom positions. ${ }^{2}$ The dredge number (Dxx) is followed by the rock number in that dredge haul.

Fe-Mn crusts collected from the slopes into the central valley (dredge D02 in area B; Table 1) are typical black crusts (Figure 2a), while Fe-Mn crusts collected from the top of the plateau (dredges D05, D06, D07, D09, D10, D11, D15, and D17 in areas A1 and A2) were black with a whitish haze through most of the crust thickness (Figure 2). The whitish haze indicates that the Fe-Mn crust was phosphatized, as confirmed by X-ray diffraction and chemical composition (see the Results section for details). Some of the plateau phosphatized crusts have an overlying 1-10 mm-thick black non-phosphatized layer. Additionally, crusts from the plateau show off-white to pinkish phosphorite lenses of variable sizes. The main substrate rocks for the crusts are basalt (Figure 2a), sandstone (Figure 2e), carbonates (Figure 2f), and ironstone (Figure 2c), however, most commonly the crusts collected were detached from their substrate. The Fe-Mn crusts on the plateau in area A2 were strongly eroded, as indicated by their polished surface, ultimately resulting in only remnants of a Fe-Mn crust on the basalt surfaces (Figure $2 \mathrm{~h}$ ). Brown ironstone material is frequently observed as vertical flame-like structures within Fe-Mn crusts (Figure 2b), as wavy laminations serving as a substrate for Fe-Mn crusts (Figure 2e), or as laminae between the Fe-Mn crust layers (Figure 2c,f). 


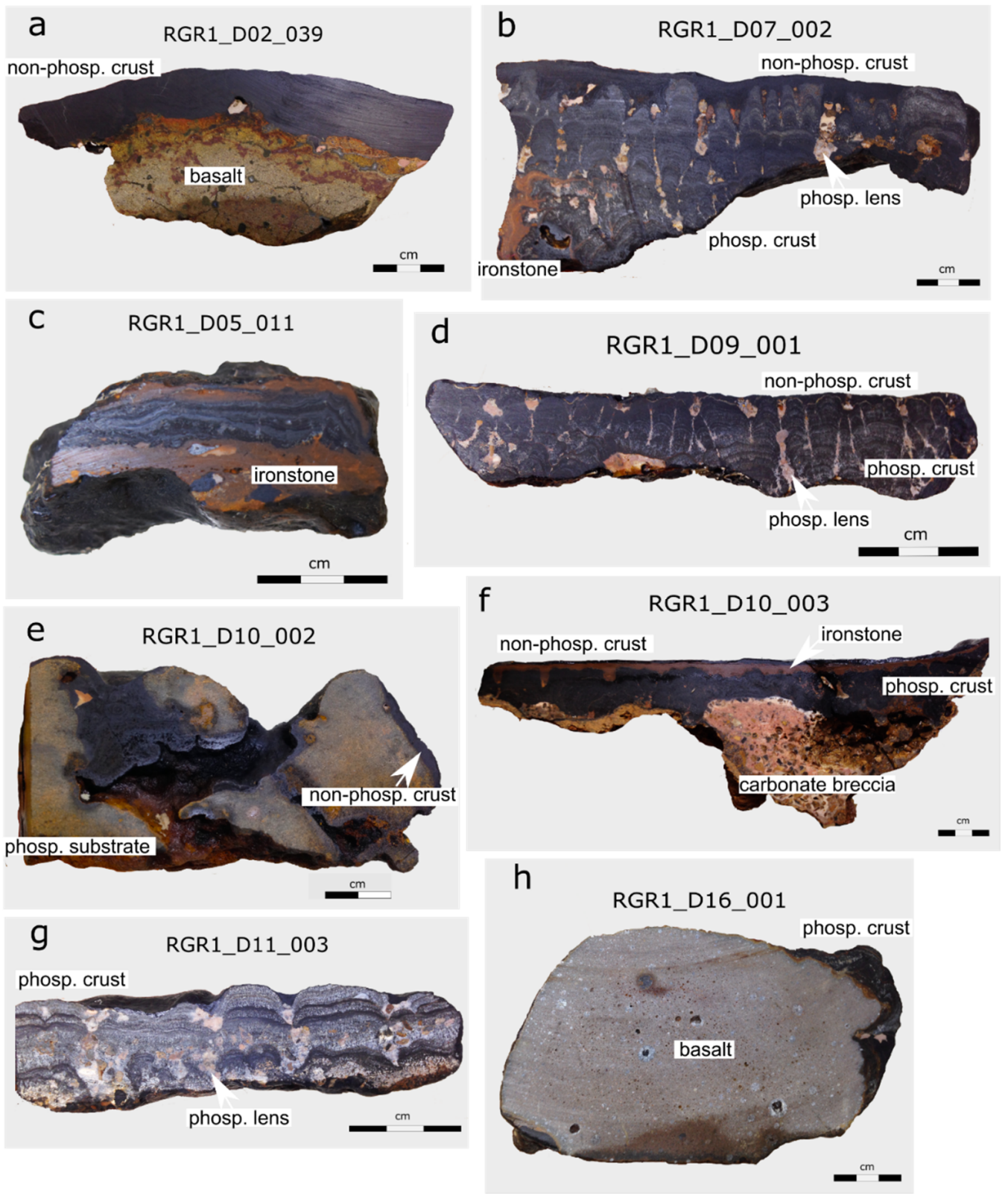

Figure 2. Examples of Fe-Mn crusts from the RGR. Non-phosp. crust = non-phosphatized Fe-Mn crust; phosp. crust $=$ phosphatized Fe-Mn crust; phosp. lens = phosphorite lenses. (a) A typical non-phosphatized crust on altered basalt; (b) phosphatized Fe-Mn crust (white haze) and pink phosphorite lenses between Fe-Mn crust columns; a thin black non-phosphatized crust overlies the phosphatized crust (white haze); ironstone material is present (lower left); no substrate rock was collected; (c) Fe-Mn crust between two ironstone layers; (d) thin non-phosphatized Fe-Mn layer capping phosphatized Fe-Mn crust and phosphorite lenses; (e) anomalous diagenetic non-phosphatized Fe-Mn crust (see results section for details) above a sandstone; (f) phosphatized Fe-Mn crust on carbonate-clast breccia; a thin non-phosphatized Fe-Mn layer is at the top; an ironstone layer is present; (g) pervasively phosphatized Fe-Mn crust with more pronounced white haze and phosphorite lens; and (h) eroded phosphatized Fe-Mn crust on basalt.

The mineralogy, chemical, and Sr isotopes composition measurements were performed in bulk Fe-Mn crusts, Fe-Mn crust layers (specified by the sample ID followed by "L" plus the depth interval in millimeters, e.g., "RGR1_D02_022 L0-10"), phosphorite lenses (specified by the ID of the layer in which they are contained plus "lens", e.g., "RGR1_D07_002 L8-33 lens"), and substrate. 


\subsection{Methods}

\subsubsection{Computed Tomography (CT)}

A three-dimensional CT scan of sample RGR1_D07_002 was made using an Xradia Versa XRM-510 scanner from Zeiss, at the Technological Characterization Laboratory from Escola Politécnica, Universidade de São Paulo, in Brazil. A slab of sample RGR1_D07_002 was scanned for $3 \mathrm{~h}$ using a $160 \mathrm{kV}$ and $10 \mathrm{~W} X$-ray source under a $36 \times$ objective. The number of views was 1000 at $8 \mathrm{~s}$ per view and the detector resolution was 1024 pixels $\times 1024$ pixels, each pixel having a 54- $\mu \mathrm{m}$ size.

\subsubsection{Mineralogy}

The mineralogy of 42 subsamples from the $22 \mathrm{Fe}-\mathrm{Mn}$ crusts was analyzed by X-ray diffraction (XRD) using a Phillips diffractometer with Cuk $\alpha$ radiation and carbon monochromator at the United States Geological Survey (USGS) in Santa Cruz, California, USA. The powder from different subsamples was drilled using a Dremel and crushed in an agate mortar. XRD scans were from 4 to $70^{\circ} 2 \theta$. Three subsamples of the Fe-Mn crusts were heated to $300^{\circ} \mathrm{C}$ for $24 \mathrm{~h}$ to check if the $10 \AA$ peak corresponds to a phyllomanganate or a tectomanganate. The percentages of minerals in the samples were determined semiquantitatively based on the intensity of the peaks and weighting factors relative to quartz [23,24]. Mineral compositions were divided into three semiquantitative categories based on the estimated percentages: major $(>25 \%)$, moderate $(5-25 \%)$, and minor $(<5 \%)$.

\subsubsection{Scanning Electron Microscopy (SEM)}

Four polished thin sections of samples RGR1_D02_039, RGR1_D05_011, RGR1_D09_001, and RGR1_D09_002 were carbon-coated and observed using a Leo 440i from Leo Electron Microscopy Ltd. at the Laboratory of Scanning Electron Microscopy (LabMEV), Instituto de Geociências, Universidade de São Paulo. The observations were performed under a high vacuum with an electron high tension (EHT) of $20 \mathrm{keV}$, work distance of $25 \mathrm{~mm}$ and an ion probe current of 1-2 nA. Backscatter electron (BSE) and secondary electron (SE) micrographs were created. Chemical element maps were carried using energy dispersive spectroscopy (EDS) with a $\mathrm{Si}$ (Li) solid-state detector with INCA 300 software from Oxford Microanalysis.

\subsubsection{Purification of Carbonate Fluorapatite (CFA)}

Chemical procedures for leaching were carried out to eliminate the Fe and Mn (oxyhydr)oxide phases, carbonates, and organic matter to obtain purified CFA aliquots for Sr isotope and chemical composition analyses. The procedures used were based on those from [25]. Step 1: $15 \mathrm{Fe}-\mathrm{Mn}$ crust layers and bulk had their Fe and Mn (oxyhydr)oxides were eliminated using a reductant made of Na-citrate, Na-bicarbonate, and Na-dithionite $(\mathrm{pH} 8)$ and the solution was filtered to collect the solid filtrate. Step 2: The residual powder from step 1 and powder samples from three phosphorite lenses had the carbonate removed by using a $0.5 \mathrm{M}$ triammonium citrate solution $(8.1 \pm 0.1)$ and filtered to collect the solid filtrate [26]. Step 3: The organic matter was oxidized from the residual powder of step 2 by washing with a $30 \% \mathrm{H}_{2} \mathrm{O}_{2}$ solution and centrifuging to pellet the CFA residue. At each step, the residue was analyzed by XRD to confirm the elimination of the mineral phase targeted.

\subsubsection{Chemical Composition}

Five different analytical techniques were used for element and compounds analyses of the Fe-Mn crusts, which were done at SGS Mineral Services, Canada. Fourteen Fe-Mn crusts were analyzed including 7 bulk crusts and 16 layers measurements, totalizing 23 samples. $\mathrm{Al}, \mathrm{Ca}, \mathrm{Fe}, \mathrm{K}, \mathrm{Mg}, \mathrm{Mn}, \mathrm{Na}$, $\mathrm{P}, \mathrm{Si}$, and Ti were determined from borate fused discs using $\mathrm{X}$-ray fluorescence (XRF); loss on ignition (LOI) was measured at $1000^{\circ} \mathrm{C}$; Ce, Co, Dy, Er, Eu, Gd, Ho, La, Lu, Mo, Nb, Nd, Ni, Pr, Sm, Tb, Tm, U, $\mathrm{V}, \mathrm{W}, \mathrm{Y}, \mathrm{Yb}$, and $\mathrm{Zr}$ were determined by ICP-MS using lithium metaborate fused discs; Ag, As, Ba, Be, $\mathrm{Bi}, \mathrm{Cd}, \mathrm{Cr}, \mathrm{Cu}, \mathrm{Hf}, \mathrm{Li}, \mathrm{Pb}, \mathrm{Rb}, \mathrm{S}, \mathrm{Sb}, \mathrm{Sc}, \mathrm{Sr}, \mathrm{Te}, \mathrm{Th}, \mathrm{Tl}$, and $\mathrm{Zn}$ were determined from four-acid digested 
aliquots by ICP-MS; $\mathrm{CO}_{2}$ was determined by coulometry; Se was determined by hydride generation and graphite furnace atomic absorption spectroscopy (AAS); and $\mathrm{Cl}$ and $\mathrm{F}$ were determined by an ion-specific electrode. A subgroup of the samples was analyzed for platinum group metals (PGM: Ir, $\mathrm{Pd}, \mathrm{Pt}, \mathrm{Rh}$, and $\mathrm{Ru}$ ) and $\mathrm{Au}$ by Ni-sulfide fire assay and ICP-MS by Intertrek Genalysis Perth, Australia, which included four bulk crusts and 10 crust layers.

Precision was better than 5\% for all elements, except for $\mathrm{Eu}(5.5 \%), \mathrm{Lu}(5.9 \%), \mathrm{Be}(6.9 \%), \mathrm{Pt}(18 \%)$, and $\mathrm{Cr}(33 \%)$. Accuracy was better than $5 \%$ for most elements; $5 \%$ to $10 \%$ for $\mathrm{Gd}, \mathrm{Er}, \mathrm{Tb}, \mathrm{Sm}, \mathrm{Tl}, \mathrm{Hf}, \mathrm{Th}$, $\mathrm{Pb}, \mathrm{Rb}$, and $\mathrm{Sc} ; 10 \%$ to $25 \%$ for $\mathrm{Bi}, \mathrm{Ag}$, and $\mathrm{Ti}$; and could not be determined for $\mathrm{Cl}, \mathrm{Co}, \mathrm{F}, \mathrm{Mo}, \mathrm{Nb}, \mathrm{Ni}, \mathrm{P}$, $\mathrm{V}, \mathrm{W}$, and $\mathrm{Zr}$ because they did not have certified values of the standards. However, $\mathrm{Co}, \mathrm{Cu}, \mathrm{Mo}, \mathrm{Ni}, \mathrm{P}$, $\mathrm{V}, \mathrm{Te}$, and $\mathrm{W}$ were also run by four acid digestion ICP-MS with accuracy better than $14 \%$, excepting Te and $\mathrm{W}$. No certified value of the standard material was available for $\mathrm{Nb}$, Os, and $\mathrm{Zr}$.

REE plus Y (REY) plots were made using concentrations normalized to shale (Post Archean Australian Shale, PAAS) concentrations using values from [27]. The Ce anomaly was calculated using the equation $\mathrm{Ce}_{\mathrm{sn}}{ }^{*}=2{ }^{*} \mathrm{Ce}_{\mathrm{sn}} /\left(\mathrm{La}_{\mathrm{sn}}+\mathrm{Pr}_{\mathrm{sn}}\right)$, where $\mathrm{sn}=$ shale normalized values. A correlation matrix was calculated for Pearson coefficients using the software R Studio. Q-mode factor analysis was performed using Matlab after [28].

\subsubsection{Age of Initiation and Growth-Rate Estimates of Fe-Mn Crusts Based on the Co-Chronometer}

The Co-chronometer empirical Equations of [29] and [30] were used to estimate the growth rates of Fe-Mn crusts, and from that to estimate the initiation age of crust growth at RGR. For this, the Co, $\mathrm{Fe}$, and Mn contents (wt \%) of bulk crusts and layers were used in the following Equations:

$G R=0.68 / C_{n}^{1.67}$, where $C_{n}=C o * 50 /(F e+M n)[29]$.

$G R=1.28 /(C o-0.24)[30]$.

The equation of Puteanus and Halbach (1988) was not applied to the phosphatized layers since their Co content is $<0.24$, which is the threshold required to use that equation. The Co-chronometer method assumes that the incorporation of $\mathrm{Co}$ by Fe-Mn crusts is constant over time and space. However, postdepositional processes, especially phosphatization, may alter the Co content of Fe-Mn crusts making results from these equations questionable. In this regard, we compared results from the Equation of [29] calculated by two different approaches: (1) using growth rates estimated for the phosphatized layers; and (2) using growth rates extrapolated from the non-phosphatized layers of the same sample when a non-phosphatized layer was present. We compared the results from the two approaches with the age of phosphatization determined by $\mathrm{Sr}$ isotopes to check if the Co-chronometer ages were realistic, i.e., ages of initiation of crust growth should be older than the age of phosphatization events.

\subsection{7. $\mathrm{U}$ and Th Isotopes}

The uppermost non-phosphatized Fe-Mn crust was used for U-Th dating. Four replicates (10-14 mg) were collected from five sublayers of sample RGR1_D07_002 by drill. Each sublayer was drilled using a micro mill system with a drill bit of $0.5 \mathrm{~mm}$ diameter and was spaced at $0.3 \mathrm{~mm}$. Isotopic compositions and concentrations of $U$ and Th were determined at The University of Texas at El Paso. For measurements of $U$ and Th isotopic compositions and concentrations, 10-100 mg powdered sample were weighed in a Teflon vial, spiked with a mixed ${ }^{233} \mathrm{U} \_{ }^{229} \mathrm{Th}$, and completely dissolved using an $\mathrm{HCl}-\mathrm{HF}$ acid mixture. Uranium and Th separation and purification were performed by anion-exchange chromatography. The total procedural blanks were $10 \mathrm{pg}$ for $\mathrm{U}$ and $30 \mathrm{pg}$ for Th, which were negligible about the amounts of $\mathrm{U}$ and $\mathrm{Th}$ in the samples. Isotope measurements were performed using a $\mathrm{Nu}$ Instruments Nu Plasma MC-ICP-MS. A sample-standard bracketing method was used to correct for instrumental mass bias. $\mathrm{U}$ concentrations were calculated using the measured ${ }^{235} \mathrm{U} /{ }^{233} \mathrm{U}$ isotopic ratios. $\left({ }^{234} \mathrm{U} /{ }^{238} \mathrm{U}\right)$ activity ratios were calculated using the analyzed ${ }^{234} \mathrm{U} /{ }^{235} \mathrm{U}$ ratios and assuming a constant ${ }^{238} \mathrm{U} /{ }^{235} \mathrm{U}$ ratio of 137.88 , with the following decay constants: $\lambda 238=1.551 \times 10^{-10} \mathrm{yr}^{-1}$ and $\lambda 234=2.826 \times 10^{-6} \mathrm{yr}^{-1}[31,32]$. Duplicate analyses of basalt BCR-2 rock standard $(N=5)$ yielded a 
mean $\left({ }^{234} \mathrm{U} /{ }^{238} \mathrm{U}\right)$ activity ratio of $1.004 \pm 0.004$, a mean $U$ concentration of $1.685 \pm 0.003$ ppm, a mean $\left({ }^{230} \mathrm{Th} /{ }^{232} \mathrm{Th}\right)$ activity ratio of $0.889 \pm 0.031$, and a mean Th concentration of $5.880 \pm 0.057 \mathrm{ppm}$. These values are consistent with previously published values [33]. In order to improve the degree of certainty of the model for the growth rate, a final U-Th analysis of the outermost rind (close of the 0 age) of sample RGR1_D07_002 was conducted at the University of California, Santa Cruz W.M. Keck Isotope Facility (Santa Cruz, CA, USA). A $10 \mathrm{mg}$ sample was digested as described above, spiked with a mixed ${ }^{229} \mathrm{Th}-{ }^{236} \mathrm{U}$ tracer. Thorium and uranium isotopic compositions were measured by thermal ionization mass spectrometry (TIMS) in an IsotopX Phoenix x62.

\subsubsection{Sr Isotopes}

Sr was isolated from pure CFA and carbonates samples by Sr-spec column chemistry at the University of California, Santa Cruz W.M. Keck Isotope Facility. The samples were digested in concentrated $\mathrm{HNO}_{3}$ and the resulting solution was separated from residual solids by centrifuge. Then, the solution was loaded onto the columns containing Sr-SPEC RESIN and the residual solution containing Sr was collected in Teflon vials. ${ }^{87} \mathrm{Sr}$ and ${ }^{86} \mathrm{Sr}$ isotopes were determined by thermal ionization mass spectrometry (TIMS) in an IsotopX Phoenix x62. The 2SD was less than $0.000091 . ~ T h e{ }^{87} \mathrm{Sr} /{ }^{86} \mathrm{Sr}$ ratios of the samples were compared to ${ }^{87} \mathrm{Sr} /{ }^{86} \mathrm{Sr}$ ratios for Cenozoic seawater and corresponding numerical ages were obtained using the LOWESS 5 fit curve from [34].

\section{Results}

\subsection{Mineralogy}

Fe-Mn crusts from RGR are composed predominantly of Mn oxides, amorphous FeOOH, minor to major amounts of carbonate fluorapatite (CFA) and calcite, and minor amounts of quartz (Table 2), as determined by the XRD patterns (Supplementary Material Figure S1). CFA is the main phosphate mineral that impregnates Fe-Mn crusts during phosphatization events, and it has white to off-white colors, which accounts for the whitish haze in phosphatized Fe-Mn crusts.

The mineralogical terminologies of marine Mn oxides are not always clear and often divergent, however, the compilation of [35] was used here because it offers a practical guide based on systematic descriptions of crystallographic features based on synchrotron studies. Two types of Mn oxides were observed in the Fe-Mn crusts of RGR. The first has no basal reflection and diagnostic reflections at $2.45 \AA$ and $1.42 \AA$, which correspond to the disordered phyllomanganate vernadite [36,37], also termed Fe-vernadite by some authors because it corresponds to Vernadite epitaxially intergrown with amorphous FeOOH [35,38,39]. The second has basal reflections at $10 \AA$ and $5 \AA$ and possible reflections overlapping with those of Vernadite at $2.45 \AA$ and $1.42 \AA$ peaks, which are together characteristic of $10 \AA$ phyllomanganates, which can be either disordered $10 \AA$ vernadite, or ordered buserite or asbolane, or a mixture of them [35,40-43]. The reflections at $10 \AA$ and $5 \AA$ could also belong to the tectomanganate todorokite, which has reflections at $9.7 \AA$ and $4.8 \AA$. However, heating three samples at $300{ }^{\circ} \mathrm{C}$ for 24 hours resulted in the collapse of the $10 \AA$ peak (Supplementary Material Figure S2), which occurs typically to the $10 \AA$ phyllomanganates asbolane and buserite and not to todorokite $[35,44,45]$.

Vernadite is the only Mn phase that composes the non-phosphatized Fe-Mn crusts from RGR, except for samples RGR1_09_002 and RGR1_D10_002 that also contain a $10 \AA$ phyllomanganate as a dominant phase. The phosphatized Fe-Mn crusts are composed of both vernadite and one or more $10 \AA$ phyllomanganates. The XRD reflections of sample RGR1_D05_011 indicate the presence of pyrolusite (Supplementary Material Figure S1), which is a Mn mineral typically formed under hydrothermal conditions [46,47]. Although no iron phases were identified in the Fe-Mn crusts by XRD, chemical composition data indicate $9 \% \mathrm{Fe}$ on average, suggesting that the $\mathrm{X}$-ray amorphous $\mathrm{FeOOH}$ is present as a nanometer-structured material. Lenses of biogenic material between the Fe-Mn columns are composed predominantly of calcite and CFA with minor amounts of quartz. The brown ironstone present in many Fe-Mn crust samples is composed of major goethite, minor to major calcite, and minor to moderate amounts of CFA. 
Table 2. Mineralogy of Fe-Mn crusts and associated phosphorite and ironstones from the Rio Grande Rise; semiquantitative categories are major $>25 \%$, moderate 5-25\%, and minor $<5 \%$. CFA = Carbonate fluorapatite; $10 \AA=10 \AA$ phyllomanganate. Interpretation based on the mineralogy.

\begin{tabular}{|c|c|c|c|c|c|}
\hline Sample ID & Subsample & Major & Moderate & Minor & Interpretation \\
\hline D02_022 & L0-10 & Vernadite & Calcite & - & Non-phosphatized Fe-Mn crust \\
\hline D02_022 & L10-15 & Vernadite, $10 \AA$ & Calcite, CFA & - & Phosphatized Fe-Mn crust \\
\hline D02_030 & L0-13 & Vernadite & - & Calcite & Non-phosphatized Fe-Mn crust \\
\hline D02_030 & L13-20 & Vernadite, $10 \AA$, CFA & Calcite & - & Phosphatized Fe-Mn crust \\
\hline D02_039 & L0-10 & Vernadite & - & Quartz, calcite & Non-phosphatized Fe-Mn crust \\
\hline D02_039 & L10-15 & Vernadite & - & Calcite, dolomite & Non-phosphatized Fe-Mn crust \\
\hline D05_011 & $\mathrm{L} 2-10$ & $10 \AA$, pyrolusite & CFA, calcite & Quartz & Hydrothermal Mn layer \\
\hline D05_011 & L10-19 & Goethite & CFA & Quartz & Ironstone \\
\hline D05_016 & L0-1 & Vernadite, $10 \AA$, CFA & - & - & Phosphatized Fe-Mn crust \\
\hline D05_016 & L0-23 & $10 \AA$, Vernadite, CFA & Calcite & - & Phosphatized Fe-Mn crust \\
\hline D05_016 & $\mathrm{L} 23-34$ & Goethite & CFA & Calcite & Ironstone \\
\hline D06_003 & Bulk & Vernadite, $10 \AA$ & CFA & Calcite & Phosphatized Fe-Mn crust \\
\hline D06_013 & Bulk & Vernadite, $10 \AA$, CFA & Calcite & - & Phosphatized Fe-Mn crust \\
\hline D07_002 & L0-6 & Vernadite & Calcite & - & Non-phosphatized Fe-Mn crust \\
\hline D07_002 & L6-18 & Vernadite, $10 \AA$, CFA & Calcite & Minor quartz & Phosphatized Fe-Mn crust \\
\hline D07_002 & L18-33 & Vernadite, $10 \AA$ & CFA & Quartz, calcite & Moderately phosphatized Fe-Mn crust \\
\hline D07_002 & L18-33 lens & Calcite, CFA & - & Quartz & CFA-cemented biogenic particles \\
\hline D07_002 & L33-55 & Vernadite, $10 \AA$, CFA & - & - & Phosphatized Fe-Mn crust \\
\hline D07_003 & L0-5 & Vernadite & Calcite or Mg-calcite/Mn-calcite & - & Non-phosphatized Fe-Mn crust \\
\hline D07_003 & Upper L5-18 & Vernadite, $10 \AA$, CFA & - & - & Phosphatized Fe-Mn crust \\
\hline D07_003 & Lower L5-18 & CFA, Vernadite & Calcite, $10 \AA$ & - & Phosphatized Fe-Mn crust \\
\hline D07_003 & L5-18 lens & CFA, calcite & - & Quartz & CFA-cemented biogenic particles \\
\hline D07_009 & Bulk & Vernadite & - & Calcite & Non-phosphatized Fe-Mn crust \\
\hline D07_020 & L0-15 & Vernadite, $10 \AA$, CFA & Calcite, $\mathrm{Mg}$-calcite & Quartz & Phosphatized Fe-Mn crust \\
\hline D07_020 & L15-33 & CFA, Vernadite, $10 \AA$ & Calcite & - & Phosphatized Fe-Mn crust \\
\hline D09_001 & L0-1 & Vernadite, $10 \AA$ & CFA & - & Moderately phosphatized Fe-Mn crust \\
\hline D09_001 & L1-13 & CFA, Vernadite & Calcite, $10 \AA$ & - & Phosphatized Fe-Mn crust \\
\hline D09_001 & L14-28 & CFA, calcite & Vernadite, $10 \AA$ & Quartz, plagioclase & Phosphatized Fe-Mn crust \\
\hline D09_001 & L14-28 lens & CFA, calcite & - & Quartz & CFA-cemented biogenic particles \\
\hline D09_002 & L0-8 & $10 \AA$, Vernadite & - & Calcite & Non-phosphatized Fe-Mn crust \\
\hline D09_002 & L8-14 & Goethite & - & CFA, calcite & Ironstone \\
\hline D09_003 & L1-3 & Goethite & - & Calcite & Ironstone \\
\hline D09_003 & L1-3 lens & Calcite, Mg-calcite & - & Minor CFA & Carbonate lens \\
\hline D10_002 & L0-2 & Vernadite, $10 \AA$, calcite & - & - & Non-phosphatized Fe-Mn crust \\
\hline D10_002 & Substrate & CFA & Calcite & Quartz & Phosphatized carbonate sand \\
\hline
\end{tabular}


Table 2. Cont

\begin{tabular}{|c|c|c|c|c|c|}
\hline Sample ID & Subsample & Major & Moderate & Minor & Interpretation \\
\hline D10_003 & L0-2 & Vernadite & - & Calcite & Non-phosphatized Fe-Mn crust \\
\hline D10_003 & $\mathrm{L} 2-5$ & Goethite & Calcite & & Ironstone \\
\hline D10_003 & L5-20 & CFA & - & Calcite, pyrolusite & Phosphorite lamina, minor hydrothermal component \\
\hline D11_003 & Bulk & CFA & $10 \AA$, calcite & Goethite, Vernadite & Pervasively phosphatized Fe-Mn crust \\
\hline D11_004 & Bulk & Vernadite, $10 \AA$ & CFA & Calcite & Moderately phosphatized Fe-Mn crust \\
\hline D15_017 & Bulk & Vernadite, $10 \AA$, CFA & Calcite & Quartz & Phosphatized Fe-Mn crust \\
\hline D17_016 & L0-20 & Goethite & - & Calcite & Ironstone \\
\hline D17_017 & Bulk & Calcite & $10 \AA$, Vernadite, CFA & & Biocalcite-rich Fe-Mn crust, moderately phosphatized \\
\hline
\end{tabular}




\subsection{Structure of Fe-Mn Crusts and Associated Minerals}

Three-dimensional CT revealed the internal structure of the sample RGR1_D07_002 (Figure 3). In the image, bright shades correspond to molecularly denser material, while dark shades correspond to less-dense material. The non-phosphatized Fe-Mn crust was massive and less bright than the phosphatized Fe-Mn crust, indicating that the phosphatized layers had a higher density. The phosphatized Fe-Mn crust had, in general, a columnar structure with columns 10-20 mm wide and up to $10 \mathrm{~mm}$ high. Trapped biogenic particles are present between the columns and correspond dominantly to foraminifera tests, as observed by SEM (Figure 4). Ironstone material was present and was denser than the Fe-Mn crust. Its flame-like structures were observed entering and spreading vertically and horizontally between layers of phosphatized Fe-Mn crust.

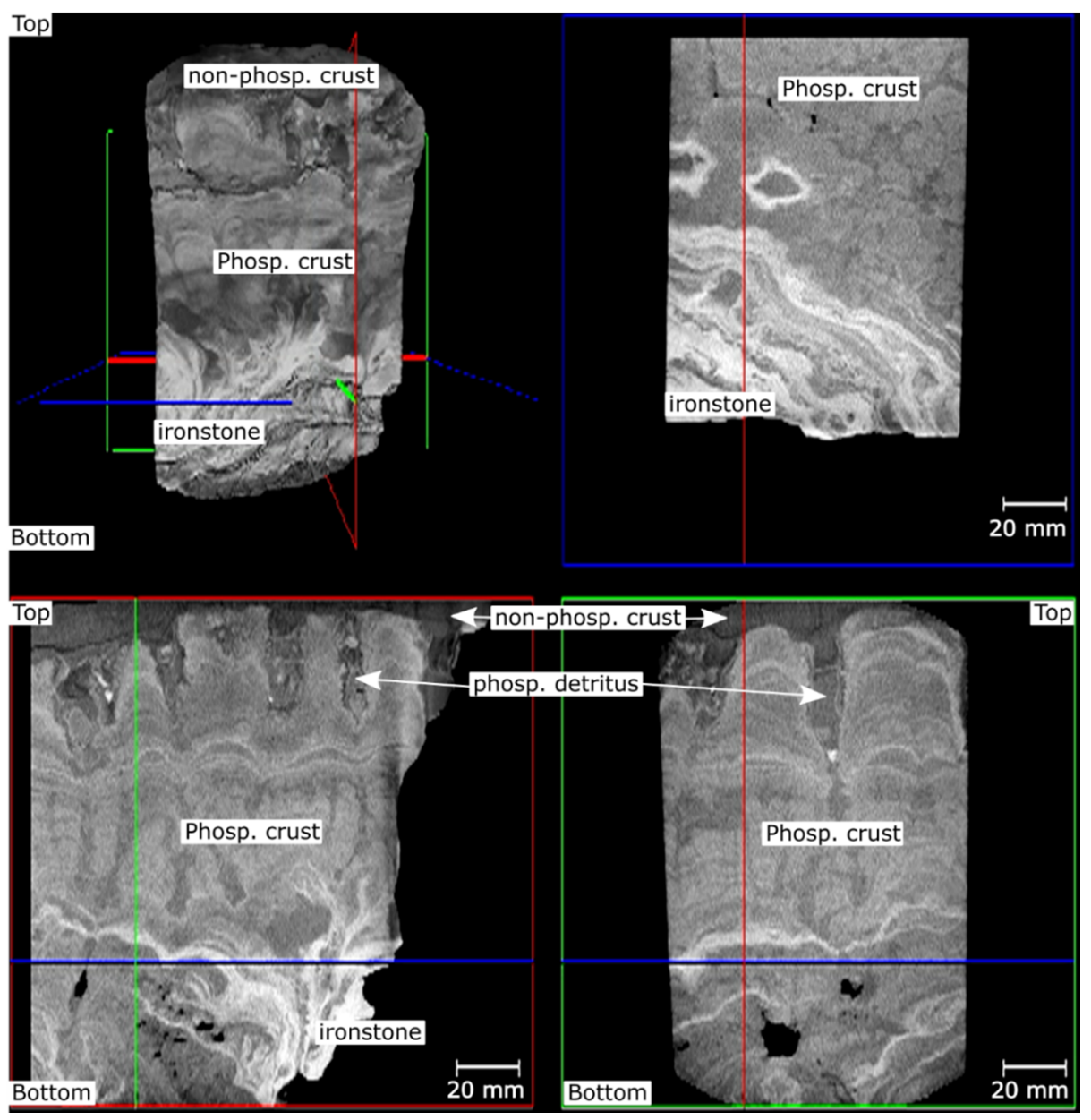

Figure 3. Three-dimension computed tomography image of sample RGR1_D07_002. Non-phosp. crust = non-phosphatized Fe-Mn crust; Phosp. crust = phosphatized Fe-Mn crust; Phosp. Detritus = biogenic particles cemented by CFA between Fe-Mn columns. Red, green, and blue squares and lines correspond to cross-section views of the sample displayed in the top left. Red = x-section; green = y-section; and blue = z-section.

SEM micrographs revealed that the texture of the non-phosphatized top crust layer was botryoidal and laminated with $<10 \mu \mathrm{m}$-thick laminae (Figure $4 \mathrm{a}$ ). The columns of the phosphatized crust show arcuate growth laminae or even cauliform/botryoidal texture in which the lamina thickness was highly variable from 10 to $500 \mu \mathrm{m}$ (Figure 4c). Other areas of the phosphatized crust show a mottled texture (Figure $4 \mathrm{~b}$ ). Regardless of the texture, planktonic foraminifer tests were widespread within the crust laminae. Layers with a massive presence of foraminifera tests and Fe-Mn dendrites occurred in 
some Fe-Mn crust samples (Figure 4d), indicating periods of extreme pelagic sedimentation during crust formation.
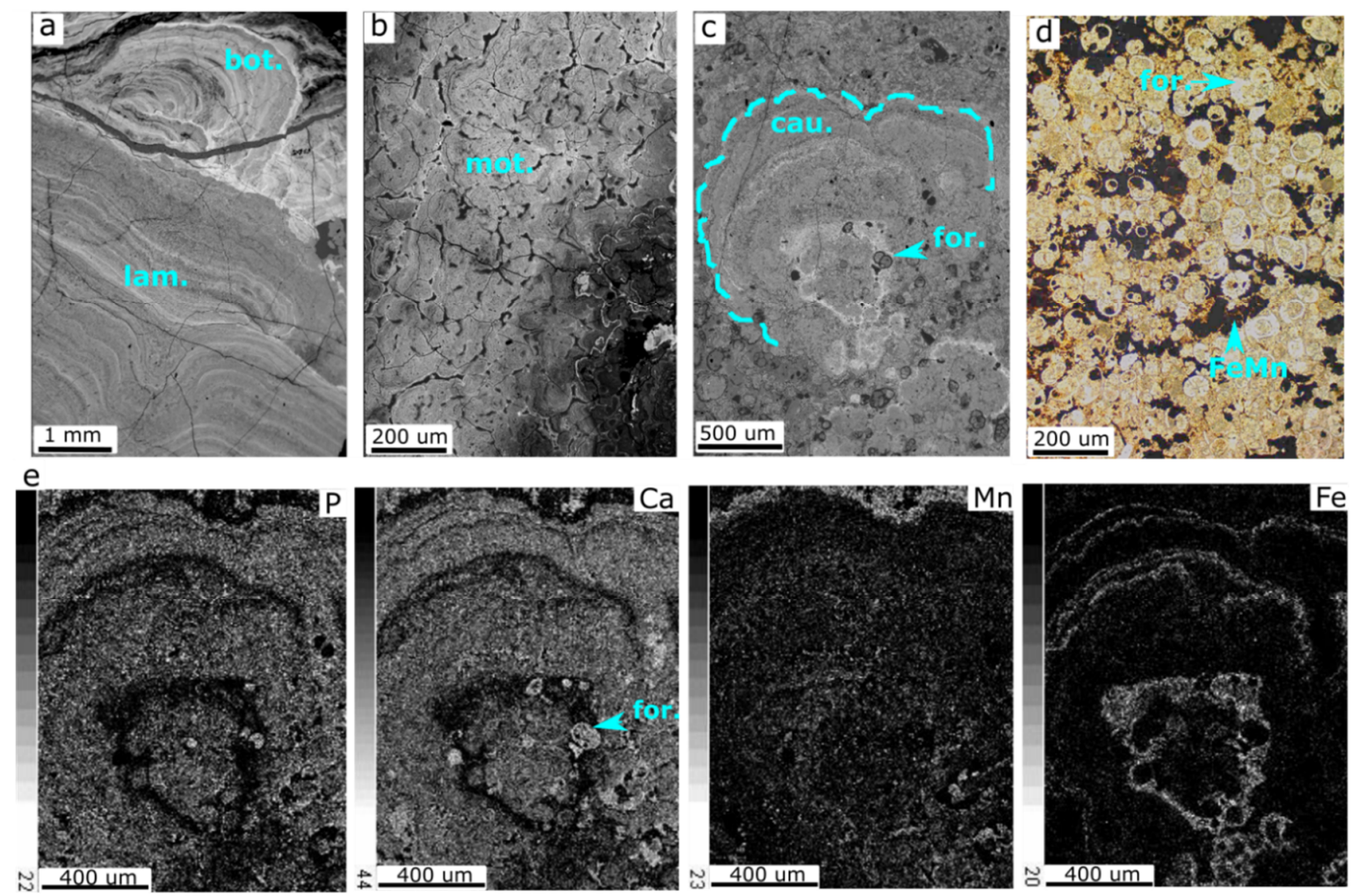

Figure 4. SEM micrographs showing different cross-section textures of Fe-Mn layers observed in crusts from the RGR. (a) Top layer of sample RGR1_D02_030 showing mostly botryoidal texture upper part and laminated texture lower part; (b) top layer of crust RGR1_D09_002 showing micro-botryoids producing a mottled texture; (c) middle layer of RGR1_D09_001 showing an isolated cauliflower structure in a mottled matrix; (d) optical microscope image of a consolidated foraminifera ooze with Fe-Mn oxide dendrites and cement; and (e) EDS mapping of chemical elements $\mathrm{P}, \mathrm{Ca}, \mathrm{Mn}$, and Fe of the area in " $\mathrm{c}$ " showing the influence of phosphatization. Brighter areas indicated higher concentrations of each of the mapped elements. Lam. = laminated; cau. = cauliflower; bot. = botryoidal; for. = foraminifer tests; FeMn = Fe-Mn dendrites.

From EDS chemical maps, the impregnation of the Fe-Mn crust matrix by CFA was seen by the $\mathrm{Ca}$ and P maps (Figure 4e). In general, CFA is present in Mn-rich layers but is not detected in Fe-rich layers. Mn and Fe distributions mostly overlap but there are Fe-rich, Mn-depleted layers, and vice versa, although the latter is less frequently observed.

\subsection{Chemical Composition}

The chemical composition of each sample is provided in Supplementary Material Table S1. The summary statistics of chemical data of Fe-Mn crusts were compiled for four different datasets: Bulk crusts $(n=14)$, combined bulk crusts and layers $(n=29)$, non-phosphatized layers $(n=6)$, and phosphatized layers ( $n=16$; Supplementary Material Table S2). For the 14 bulk crusts, data for six were calculated by averaging the layer chemical compositions weighed by the thickness of each layer.

\subsubsection{All Data, Combined Bulk Crusts, and Layers}

The chemical composition of bulk Fe-Mn crusts and layers combined $(n=29)$, expressed as mean wt \% (min-max\%) was 16.6\% Ca (3.93-29.5\%), 15.0\% Mn (5.06-24.5\%), 9.06\% Fe (2.21-19.1\%), 3.94\% $\mathrm{P}(0.43-7.67 \%), 2.43 \% \mathrm{Mg}(1.42-5.30 \%), 1.38 \% \mathrm{Al}(0.60-3.70 \%), 0.91 \% \mathrm{~F}(0.03-1.85 \%)$, and $0.61 \% \mathrm{Si}$ 
(0.41-1.14\%; Supplementary Material Table S2). An important characteristic of RGR Fe-Mn crusts was the low mean Fe/Mn ratio of 0.56 (0.28-1.10), which contrasts with the mean Fe/Mn ratios for other crust deposits, 0.74-2.67 [5]. The mean Si/Al ratio was 0.54 (0.19-1.22), which is also atypical, showing a strong enrichment of $\mathrm{Al}$ relative to $\mathrm{Si}$; these were much lower ratios than typical for volcanic and sedimentary rocks (e.g., 3.37 for basalts; [48]). The mean Ca/P ratio for the crusts was 6.25 (2.97-17.1).

The contents of elements of greatest economic interest were 3073 ppm Co (912-8586 ppm), 400 ppm Cu (117-1557 ppm), 5595 ppm Ni (3000-11015 ppm), 1333 ppm total REY (138-3189 ppm), 731 ppm V (246-1219 ppm), 342 ppm Mo (135-630 ppm), and 117 ppm W (38-305 ppm). The \%HREY complement of the total REY (Heavy REY = Eu, Gd, Tb, Dy, Ho, Er, Tm, Yb, Lu, and Y) is on average $33 \%(11-50 \%)$, which is much higher than crusts found elsewhere [10], although total REY contents were low. The highest individual REY concentrations were Ce (34.1-2159, mean 631ppm), Y (40.7-802, mean 222 ppm), La (23.0-371, mean 163 ppm), and Nd (16.1-324, mean 138 ppm). The highest mean platinum group metals (PGM) were 360 ppb Pt (49.3-765 ppb), 34.1 ppb Rh (3.08-94.0 ppb), and $15.8 \mathrm{ppb} \mathrm{Ru}(1.03-45.7 \mathrm{ppb})$.

Other elements of high concentrations in the RGR crusts were Li (2.56-330, mean 100 ppm) and especially Te (4.04-106 ppm, mean 38.9 ppm).

The mean bulk Fe-Mn crust element contents had the same trends as for the entire dataset, which shows pervasive phosphatization for most samples, consistent with the mineralogy (Supplementary Material Table S2).

\subsubsection{Non-Phosphatized Fe-Mn Crust}

Seven non-phosphatized Fe-Mn crust layers from RGR were analyzed for chemical composition, but only six of them were used for statistics because sample RGR1_D10_002 was an outlier for some elements, especially Mg, Al, Li, F, and Cu, as described below (Supplementary Material Figure S3). The mean chemical composition of six non-phosphatized Fe-Mn crust layers was higher for Fe, Mn, $\mathrm{Na}, \mathrm{K}, \mathrm{Ti}, \mathrm{V}, \mathrm{Cl}$, and $\mathrm{Ni}$ compared to the bulk composition, while it was lower for $\mathrm{Ca}, \mathrm{Si}, \mathrm{Al}, \mathrm{Mg}, \mathrm{S}$, and F. The non-phosphatized crusts have $\mathrm{Fe} / \mathrm{Mn}$ ratios between 0.67 and 0.83 (mean 0.75 ), mean $\mathrm{Si} / \mathrm{Al}$ is 0.82 (0.45-1.22), and mean $\mathrm{Ca} / \mathrm{P}$ is 11.3 (7.31-17.12), all of which were higher compared to the bulk crusts.

The contents of elements of greatest economic interest $(\mathrm{Co}, \mathrm{Cu}, \mathrm{Ni}$, total $\mathrm{REY}, \mathrm{V}, \mathrm{Mo}, \mathrm{W}$, and $\mathrm{Nb}$ ) were higher in the non-phosphatized crusts than in the bulk crust, except for Cu and W. The \%HREY complement of the total REY was on average 13.6\% (10.7-15.4\%), which was lower than typical crusts from other areas. The mean individual REY concentrations were higher in non-phosphatized Fe-Mn crusts than in the bulk crusts and phosphatized crust layers. Mean PGM contents were much higher in the non-phosphatized crust than in the bulk crusts, for example, Pt (mean $661 \mathrm{ppb}$ ). Other elements of mean high concentrations in the RGR non-phosphatized crusts are Bi (62.7 ppm), Nb (106 ppm), and Te (96.3 ppm); the mean Te content was very high compared to other crusts.

Sample RGR1_D10_002 shows an anomalously high content of Al (3.70\%), Mg (5.31\%), F (1.16\%), $\mathrm{Ni}(1.10 \%), \mathrm{Cu}(1557 \mathrm{ppm}), \mathrm{Li}(330 \mathrm{ppm})$, and Zn (951 ppm) compared to the mean contents for non-phosphatized Fe-Mn crust layers from RGR.

\subsubsection{Phosphatized Fe-Mn Crusts}

The phosphatized Fe-Mn crusts show higher mean contents of $\mathrm{Ca}, \mathrm{Mg}, \mathrm{Si}, \mathrm{Al}, \mathrm{P}, \mathrm{S}, \mathrm{F}$, and $\mathrm{CO}_{2}$ and lower contents of $\mathrm{Fe}, \mathrm{Mn}, \mathrm{Na}, \mathrm{K}, \mathrm{Ti}$, and $\mathrm{Ni}$ than non-phosphatized crusts (Supplementary Material Table S2). The mean Fe/Mn ratio was 0.52 and varied from 0.28 to 1.10, which was lower than that of the non-phosphatized crusts. The wide variations of $\mathrm{Ca}, \mathrm{P}$, and F reflected the degree of phosphatization as was also determined by the mineralogy, ranging from mildly phosphatized to pervasively phosphatized samples. Mean Si/Al was 0.42 (0.22-0.64), which was lower than that of the non-phosphatized crusts and similar to typical volcanic and sedimentary rocks (e.g., 3.37 for basalts; [48]). Ca/P was 4.19 on average (2.97-8.05) and was lower than the mean of 7.31 of non-phosphatized crusts. 
The contents of elements that are typical of greatest economic interest were Co $1546 \mathrm{ppm}$ (912-2889 ppm), Cu 362 ppm (118-737 ppm), total REY 793 ppm (138-2396 ppm), V 564 ppm (246-1209 ppm), Mo 241 ppm (135-332 ppm), Nb 22.3 ppm (5.14-56.8 ppm), Te 16.3 ppm (4.04-37.1 ppm), and $\mathrm{W} 117 \mathrm{ppm}$ (38.2-305 ppm). Co, V, Mo, Nb, Te, and total REY contents in the phosphatized crusts were much lower than in non-phosphatized crusts, whereas $\mathrm{W}$ was relatively more enriched.

Other elements in high concentration in the phosphatized RGR crusts were $\mathrm{Li}$ (30.9-217, mean $127 \mathrm{ppm}$ ), which was much more enriched compared to the non-phosphatized crust, and the \%HREY (29.1-50.2\%, mean $40.8 \%$ ), which was also very high compared to the non-phosphatized crusts and similar to the range determined for marine phosphorites by [49]. The highest individual REY concentrations were Ce (34.1-426, mean 195 ppm), Y (40.7-802, mean 237 ppm), La (23.0-370, mean $120 \mathrm{ppm})$, and $\mathrm{Nd}$ (16.1-324, mean $99.8 \mathrm{ppm})$. Except $\mathrm{Y}$, mean individual REY as well as $\mathrm{Pt}, \mathrm{Rh}$, and $\mathrm{Ru}$ contents in the phosphatized crusts were much lower than in non-phosphatized crusts.

\subsection{Correlation between Elements}

\subsubsection{Non-Phosphatized Fe-Mn Crusts}

Correlation coefficients for chemical elements in the non-phosphatized Fe-Mn crusts from RGR ( $n=7$; Supplementary Material Table S3) show no correlation between Fe and Mn at the 95\% confidence level (CL), suggesting that the two phases they represent were independent variables. Significant positive correlations at the $99 \% \mathrm{CL}$ exist between $\mathrm{Fe}$ and $\mathrm{Na}, \mathrm{K}, \mathrm{Ba}, \mathrm{Bi}, \mathrm{Pb}, \mathrm{Sb}, \mathrm{Sr}, \mathrm{Te}, \mathrm{U}$, and all the REY; positive correlations at the $95 \% \mathrm{CL}$ also existed between $\mathrm{Fe}$ and $\mathrm{As}, \mathrm{Cl}$, and $\mathrm{Zr}$. Significant negative correlations at the $99 \% \mathrm{CL}$ occurred between $\mathrm{Fe}$ and $\mathrm{Al}, \mathrm{Mg}, \mathrm{Cd}, \mathrm{Cu}, \mathrm{F}, \mathrm{Li}, \mathrm{Ni}, \mathrm{Zn}$, and the HREY. In the non-phosphatized crusts, Mn had no significant positive correlation above the $95 \%$ CL. Significant negative correlations $(R<-0.85)$ existed between $\mathrm{Mn}$ and $\mathrm{Si}(99 \% \mathrm{CL}), \mathrm{Ca}(99 \% \mathrm{CL})$, and $\mathrm{CO}_{2}(95 \% \mathrm{CL})$. Silicon was correlated with $\mathrm{Ca}$ and $\mathrm{CO}_{2}$ (both $95 \% \mathrm{CL}$ ) suggesting a biogenic phase(s) composed of calcium carbonate and silica. $\mathrm{Al}, \mathrm{Mg}, \mathrm{Cd}, \mathrm{Cu}, \mathrm{Li}, \mathrm{Ni}$, and $\mathrm{Zn}$ were correlated with each other at the $99 \%$ $\mathrm{CL}$ and each of them was negatively correlated with Fe and show no correlation at the 95\% CL with $\mathrm{Mn}, \mathrm{Ca}, \mathrm{CO}_{2}, \mathrm{Si}$, or $\mathrm{P}$. Thus, $\mathrm{Al}, \mathrm{Mg}, \mathrm{Cd}, \mathrm{Cu}, \mathrm{Li}, \mathrm{Ni}$, and $\mathrm{Zn}$ were not strongly or solely associated with any mineral group of phase, suggesting the existence of a residual biogenic phase. $\mathrm{Pt}$ was significantly correlated with $\mathrm{Fe}$, Ti, and $\mathrm{P}$ (at the $99 \% \mathrm{CL}$ ), while $\mathrm{Rh}$ was correlated with $\mathrm{Bi}, \mathrm{Cd}, \mathrm{Pb}$ (99\% CL), and $\mathrm{Nb}(95 \% \mathrm{CL})$. Ru was correlated with Bi and some HREY (Y, Er, Ho, Tm, Yb, and $\mathrm{Lu}$ ) at the $99 \% \mathrm{CL}$, and to $\mathrm{Ti}$ at the $95 \% \mathrm{CL}$.

\subsubsection{Phosphatized Fe-Mn Crusts}

The phosphatized Fe-Mn crust layers show a correlation between $\mathrm{Fe}$ and $\mathrm{Mn}$ at the $99 \% \mathrm{CL}$ (Supplementary Material Table S4). Iron correlates positively with $\mathrm{As}, \mathrm{Ba}, \mathrm{Co}, \mathrm{Cr}, \mathrm{Sb}$, and $\mathrm{V}$ at the $99 \%$ $\mathrm{CL}$, and negatively with $\mathrm{Ca}, \mathrm{P}, \mathrm{S}$, and F. Manganese correlates with $\mathrm{V}, \mathrm{Be}, \mathrm{Co}, \mathrm{Ni} \mathrm{Tl}$, and $\mathrm{Zn}$ at the $99 \%$ $\mathrm{CL}$, and at the $95 \% \mathrm{CL}$ with $\mathrm{Mg}, \mathrm{As}, \mathrm{Ba}, \mathrm{Cl}, \mathrm{Mo}, \mathrm{Pb}$, and $\mathrm{Sb}$. Negative correlations existed between $\mathrm{Mn}$ and $\mathrm{Ca}$ and $\mathrm{CO}_{2}(99 \% \mathrm{CL})$ and between $\mathrm{Mn}$ and $\mathrm{P}$ and $\mathrm{S}(95 \% \mathrm{CL})$. The correlation between $\mathrm{Si}$ and $\mathrm{CO}_{2}$ was significant at the $99 \% \mathrm{CL}$ but $\mathrm{Si}$ and Ca did not correlate at the $95 \% \mathrm{CL}$, and $\mathrm{Si}$ had a negative correlation with P and F (95\% CL), indicating that $\mathrm{Si}$ was not related to the CFA phase. Si shows a correlation with elements $\mathrm{Al}, \mathrm{Ti}, \mathrm{Cu}, \mathrm{Mo}$, and $\mathrm{Nb}$ at the $95 \% \mathrm{CL}$. Positive correlations between $\mathrm{P}$ and $\mathrm{Ca}, \mathrm{F}, \mathrm{S}, \mathrm{Sr}, \mathrm{U}$, and the HREY occurred at the $99 \% \mathrm{CL}$, reflecting the CFA phase.

\subsection{Factor Analysis}

Q-mode factor analysis of the chemical composition of non-phosphatized and phosphatized Fe-Mn crusts from RGR resulted in a different number of factors that were interpreted to represent different mineral phases and their hosted elements (Table 3). Three factors explained $93.5 \%$ of the variance of the chemical data of the non-phosphatized crust. Factor 1 was interpreted to represent a mixture of Fe and Mn (oxyhydr)oxide phases (43.1\% of variance) including elements typically associated to the 
Fe-oxyhydroxide phase $(\mathrm{Nb}, \mathrm{Zr}, \mathrm{As}, \mathrm{Pb}, \mathrm{Ti}$, and $\mathrm{Bi}$ ) and to Mn-oxide $(\mathrm{Ba})$, and those partitioned between both phases (Te and V; [1]). Factor 2 represents a residual biogenic phase (17.7\% of the variance) and includes elements with a nutrient-type distribution in ocean water ( $\mathrm{P}, \mathrm{Ni}, \mathrm{Cu}, \mathrm{Zn}$, and $\mathrm{Cd})$, associated with organic matter (Ca, Mg, Fe, and F), or are biointermediate elements (Mo; [50]). Factor 3 (33.2\% of the variance) represents a mixture of biocarbonates ( $\mathrm{Rb}, \mathrm{Th}, \mathrm{Ba}$, and $\mathrm{Sr})$ and biosilica $(\mathrm{Si})$.

Table 3. Q-mode rotated factor scores for the chemical composition of non-phosphatized and phosphatized crusts from RGR (bold are elements that indicate the major phase(s)).

\begin{tabular}{|c|c|c|c|c|c|c|c|c|c|c|c|c|c|}
\hline \multicolumn{6}{|c|}{ Non-Phosphatized Crust } & \multicolumn{8}{|c|}{ Phosphatized Fe-Mn Crust } \\
\hline \multicolumn{2}{|c|}{$\begin{array}{c}\text { Factor } 1 \\
43.1 \%\end{array}$} & \multicolumn{2}{|c|}{$\begin{array}{c}\text { Factor } 2 \\
17.2 \%\end{array}$} & \multicolumn{2}{|c|}{$\begin{array}{c}\text { Factor } 3 \\
33.2 \%\end{array}$} & \multicolumn{2}{|c|}{$\begin{array}{c}\text { Factor } 1 \\
41.3 \%\end{array}$} & \multicolumn{2}{|c|}{$\begin{array}{c}\text { Factor } 2 \\
33.9 \%\end{array}$} & \multicolumn{2}{|c|}{$\begin{array}{c}\text { Factor } 3 \\
12.3 \%\end{array}$} & \multicolumn{2}{|c|}{$\begin{array}{c}\text { Factor } 4 \\
5.0 \%\end{array}$} \\
\hline $\mathrm{Nb}$ & 0.219 & $\mathbf{F}$ & 0.310 & Si & 0.327 & Mo & 0.287 & $\mathbf{P}$ & 0.402 & $\mathrm{Cr}$ & 0.377 & $\mathrm{Rb}$ & 0.401 \\
\hline $\mathrm{Fe}$ & 0.187 & $\mathbf{P}$ & 0.272 & $\mathrm{CO}$ & 0.298 & $\mathrm{Al}$ & 0.272 & $\mathbf{F}$ & 0.385 & $\mathrm{Ba}$ & 0.326 & $\mathrm{CO}$ & 0.384 \\
\hline Mn & 0.295 & $\mathbf{N i}$ & 0.271 & $\mathrm{Ca}$ & 0.291 & $\mathrm{Nb}$ & 0.238 & $\mathrm{Na}$ & 0.353 & $\mathrm{Sb}$ & 0.323 & $\mathrm{Ca}$ & 0.329 \\
\hline $\mathrm{Zr}$ & 0.272 & Mg & 0.270 & Th & 0.261 & Mg & 0.233 & $\mathrm{~S}$ & 0.345 & $\mathbf{V}$ & 0.317 & $\mathrm{~K}$ & 0.239 \\
\hline $\mathrm{U}$ & 0.271 & $\mathrm{Li}$ & 0.270 & $\mathrm{Rb}$ & 0.241 & $\mathrm{Zr}$ & 0.228 & $\mathrm{Ca}$ & 0.334 & Mn & 0.311 & $\mathrm{Si}$ & 0.224 \\
\hline As & 0.245 & $\mathrm{~W}$ & 0.270 & $\mathrm{Sc}$ & 0.224 & $\mathrm{Ti}$ & 0.222 & $\mathrm{Sr}$ & 0.293 & $\mathrm{Fe}$ & 0.297 & $\mathrm{Cr}$ & 0.194 \\
\hline $\mathrm{Pb}$ & 0.218 & $\mathrm{Al}$ & 0.269 & $\mathrm{Cr}$ & 0.215 & $\mathbf{L i}$ & 0.219 & $\mathrm{U}$ & 0.273 & As & 0.268 & Hf & 0.153 \\
\hline $\mathrm{Ti}$ & 0.216 & $\mathrm{Cu}$ & 0.268 & LR & 0.200 & $\mathrm{Cu}$ & 0.212 & $\mathrm{Zn}$ & 0.174 & $\mathrm{Zn}$ & 0.254 & $\mathrm{Cu}$ & 0.145 \\
\hline $\mathbf{V}$ & 0.215 & $\mathrm{Zn}$ & 0.266 & $\mathrm{RE}$ & 0.196 & $\mathrm{Ni}$ & 0.206 & HR & 0.145 & Co & 0.222 & & \\
\hline $\mathrm{Te}$ & 0.203 & $\mathrm{Rb}$ & 0.263 & Co & 0.186 & LR & 0.205 & $\mathrm{Sc}$ & 0.133 & $\mathrm{Tl}$ & 0.166 & & \\
\hline $\mathrm{Bi}$ & 0.203 & $\mathrm{Cd}$ & 0.262 & $\mathrm{Sb}$ & 0.181 & $\mathrm{RE}$ & 0.205 & & & K & 0.162 & & \\
\hline $\mathrm{Sn}$ & 0.199 & Mo & 0.240 & $\mathrm{Tl}$ & 0.168 & $\mathrm{Te}$ & 0.199 & & & $\mathrm{Be}$ & 0.157 & & \\
\hline HR & 0.198 & $\mathrm{CO}$ & 0.158 & Be & 0.165 & Th & 0.194 & & & & & & \\
\hline $\mathrm{K}$ & 0.196 & $\mathrm{Ca}$ & 0.143 & $\mathrm{Ba}$ & 0.158 & $\mathrm{~W}$ & 0.186 & & & & & & \\
\hline $\mathrm{Ba}$ & 0.193 & Si & 0.141 & $\mathrm{Sr}$ & 0.156 & $\mathbf{P b}$ & 0.172 & & & & & & \\
\hline $\mathrm{Sr}$ & 0.192 & & & $W$ & 0.144 & $\mathrm{Rb}$ & 0.162 & & & & & & \\
\hline $\mathrm{Na}$ & 0.173 & & & $\mathrm{~K}$ & 0.142 & $\mathrm{Bi}$ & 0.161 & & & & & $\mathrm{Ni}$ & -0.135 \\
\hline $\mathrm{P}$ & 0.155 & & & $\mathrm{Cl}$ & 0.141 & $\mathrm{Tl}$ & 0.154 & & & & & $\mathrm{RE}$ & -0.176 \\
\hline \multirow[t]{2}{*}{$\mathrm{Sb}$} & 0.154 & & & $\mathrm{Na}$ & 0.139 & $\mathrm{Be}$ & 0.146 & & & & & LR & -0.176 \\
\hline & & & & $\mathrm{Fe}$ & 0.133 & HR & 0.143 & & & & & $\mathrm{U}$ & -0.180 \\
\hline $\mathrm{Ca}$ & -0.113 & & & & & $\mathrm{Cd}$ & 0.134 & & & & & $\mathrm{Zr}$ & -0.192 \\
\hline $\mathrm{CO}$ & -0.132 & & & $\mathrm{Ni}$ & -0.137 & Hf & 0.132 & & & & & $\mathrm{HR}$ & -0.208 \\
\hline $\mathrm{Si}$ & -0.132 & & & $\mathrm{Mn}$ & -0.137 & $\mathrm{Si}$ & 0.131 & & & & & $\mathrm{Zn}$ & -0.215 \\
\hline
\end{tabular}

For the phosphatized crusts, four factors explained $93.2 \%$ of the variance of the chemical composition and they correspond to (Factor 1) a residual biogenic phase; (Factor 2) the CFA phase (Ca, P, F, Sr, and HREY); (Factor 3) Fe and Mn phases; and (Factor 4) a biocarbonate phase that is most likely calcite based on XRD and perhaps biosilica.

\subsection{Sr Isotopic Composition and Age Dates of Diagenetic CFA}

The CFA from phosphatized Fe-Mn crusts yielded ${ }^{87} \mathrm{Sr} /{ }^{86} \mathrm{Sr}$ ratios between 0.708408 and 0.708957 , which, when compared to the Cenozoic ${ }^{87} \mathrm{Sr} /{ }^{86} \mathrm{Sr}$ seawater curve calibrated ages, corresponds to ages that vary from 20.2 Ma to 6.8 Ma (Supplementary Material Table S5). Phosphatization affected nearly the entire thickness of the Fe-Mn crusts collected from the RGR plateau and phosphatization of the crusts ended about 6.8 Ma. Most of the ages fell into two groups, i.e. two main episodes of phosphatization: one between 20.2 and $16.0 \mathrm{Ma}$ and one between 9.9 and $6.8 \mathrm{Ma}$, with one sample at 12 Ma. In crusts RGR1_D07_002 and RGR1_D11_003, different ages were observed for different phosphatized stratigraphic layers, resulting in more recently formed layers yielding younger ages of phosphatization. For crust RGR1_D07_002, five different layers yielded ages that could be grouped into three main episodes of phosphatization: about 20.2-18.5 Myr, 15.6 Myr, and about 9.9-9.6 Myr (Figure 5). For crust RGR1_D11_003, two episodes were recognized, at 17.5 Ma and 12.5 Ma. Each age is a mean age for the stratigraphic interval sampled. 


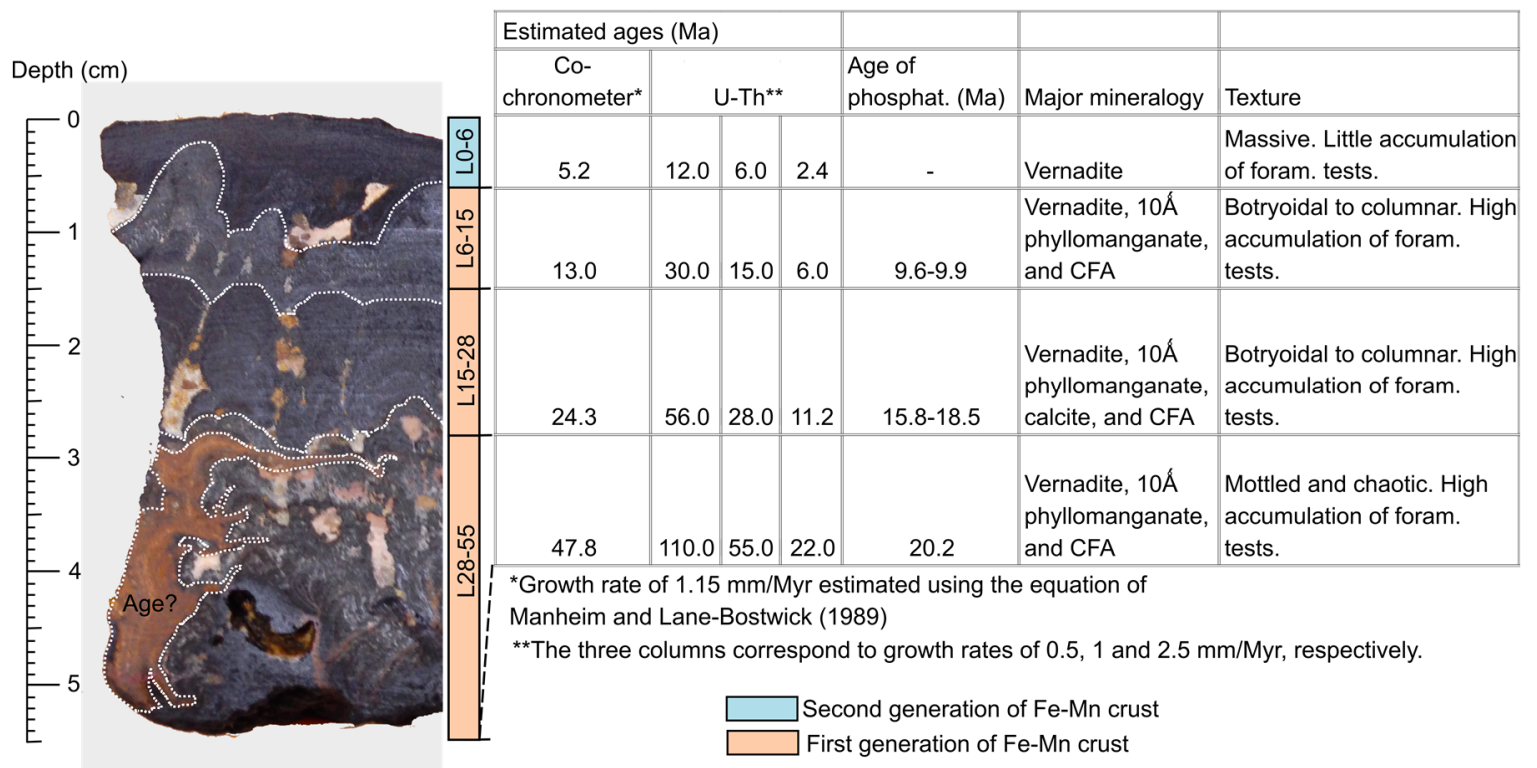

Figure 5. Stratigraphic sequence of crust RGR1_D07_002 showing estimated ages of initiation, age of phosphatization, major mineralogy, and texture of Fe-Mn layers. Layer L0-6 is the non-phosphatized second generation of the Fe-Mn crust, while layers L6-15, L15-28, and L28-55 are the phosphatized first generation of the Fe-Mn crust. Possible ages of initiation of growth on Fe-Mn layers are based on different growth rates determined by using the Co-chronometer Equation of [29] and U-Th isotopes.

\subsection{Estimated Co-Chronometer Growth Rates and Ages of Initiation}

Estimated Co-chronometer growth rates and ages of initiation of crust growth derived from the Equations of [29] and [30] for the non-phosphatized layers differed significantly (Table 4). Growth rates derived from the first Equation were between 0.57 and $1.39 \mathrm{~mm} / \mathrm{Myr}$, while the second equation resulted in much higher growth rates between 2.07 and $4.31 \mathrm{~mm} / \mathrm{Myr}$. These rates using the two different Equations result in the oldest ages of initiation of the thickest non-phosphatized crust (RGR1_02_039) of $23.15 \mathrm{Ma}$ and $6.39 \mathrm{Ma}$, respectively. The youngest ages for the initiation of crust growth were for sample RGR1_D10_003 L0-2, which were 1.44 and 0.46 Ma respectively for each equation. Growth rates resulting from the [29] Equation also differed between non-phosphatized and phosphatized layers, with phosphatized layers having higher rates, between 1.48 and $4.38 \mathrm{~mm} / \mathrm{Myr}$.

Table 4. Estimated growth rates (mm/Myr) and ages of initiation (Ma) of Fe-Mn crust formation from Rio Grande Rise based on the Co-chronometer Equations of [29] and [30]; samples shaded in brown correspond to phosphatized layers.

\begin{tabular}{lcccccccc}
\hline \multicolumn{1}{c}{ Sample ID } & mm & \multicolumn{2}{c}{ [29] $^{\mathbf{1}}$} & \multicolumn{2}{c}{ [29] $^{\mathbf{2}}$} & \multicolumn{2}{c}{ [30] $^{\mathbf{2}}$} & \multicolumn{2}{c}{$\begin{array}{c}\text { Age of } \\
\text { Phosphatization }\end{array}$} \\
\hline RGR1_D02_030_L0-13 & 13 & 0.88 & 14.70 & 0.88 & 14.70 & 2.89 & 4.49 & - \\
RGR1_D02_030_L13-20 & 7 & 2.70 & 17.29 & 0.88 & 22.62 & 2.89 & 6.91 & 16.2 \\
RGR1_D02_039_L0-10 & 10 & 0.57 & 17.41 & 0.57 & 17.41 & 2.07 & 4.83 & - \\
RGR1_D02_039_L10-15 & 5 & 0.87 & 23.15 & 0.87 & 23.15 & 3.20 & 6.39 & - \\
RGR1_D05_011_L2-10 & 8 & 4.38 & 1.83 & - & - & - & - & - \\
RGR1_D05_016_L0-19 & 19 & 2.83 & 6.72 & - & - & - & - & 9.9 \\
RGR1_D06_003_B0-8 & 8 & 3.62 & 2.21 & - & - & - & - & - \\
RGR1_D07_002_L0-6 & 6 & 1.15 & 5.23 & 1.15 & 5.23 & 3.96 & 1.52 & - \\
RGR1_D07_002_L6-18 & 12 & 3.13 & 9.06 & 1.15 & 15.68 & 3.96 & 4.55 & 9.9 \\
RGR1_D07_002_L18-33 & 15 & 3.65 & 13.17 & 1.15 & 28.75 & 3.96 & 8.34 & $15.6-18.5$ \\
RGR1_D07_002_L33-55 & 22 & 4.04 & 18.61 & 1.15 & 47.91 & 3.96 & 13.90 & 20.2 \\
\hline
\end{tabular}


Table 4. Cont.

\begin{tabular}{lcccccccc}
\hline \multirow{2}{*}{ Sample ID } & \multirow{2}{*}{$\mathbf{m m}$} & \multicolumn{2}{c}{ [29] $^{\mathbf{1}}$} & \multicolumn{2}{c}{ [29] $^{\mathbf{2}}$} & \multicolumn{2}{c}{ [30] $^{\mathbf{2}}$} & \multicolumn{2}{c}{$\begin{array}{c}\text { Age of } \\
\text { Phosphatization }\end{array}$} \\
\hline RGR1_D07_003_L0-5 & 5 & 0.92 & 5.42 & 0.92 & 5.42 & 2.90 & 1.72 & \\
RGR1_D07_003_L5-20 & 15 & 2.72 & 10.95 & 0.92 & 21.69 & 2.90 & 6.89 & 16 \\
RGR1_D09_001_L0-1 & 1 & 2.16 & 0.46 & 2.16 & - & - & - & - \\
RGR1_D09_001_L1-13 & 12 & 2.30 & 5.67 & 2.16 & - & - & - & 16.1 \\
RGR1_D09_001_L14-28 & 14 & 3.01 & 10.33 & 2.16 & - & - & - & 16.8 \\
RGR1_D09_002_B0-10 & 10 & 1.86 & 5.37 & - & - & - & - & - \\
RGR1_D10_002_L0-2 & 2 & 1.20 & 1.66 & - & - & - & - & - \\
RGR1_D10_003-L0-2 & 2 & 1.39 & 1.44 & 1.39 & 1.44 & 4.31 & 0.46 & - \\
RGR1_D10_003-L5-20 & 15 & 2.74 & 6.93 & 1.39 & 12.26 & 4.31 & 3.95 & 20 \\
RGR1_D11_003-B0-20 & 20 & 1.48 & 13.48 & - & - & - & - & - \\
RGR1_D15_017-B0-13 & 13 & 2.19 & 5.95 & - & - & - & - & 8.5 \\
RGR1_D17_017-B0-14 & 14 & 2.26 & 6.20 & - & - & - & - & 6.8 \\
\hline
\end{tabular}

${ }^{1}$ Growth rates calculated for the non-phosphatized and phosphatized layers. ${ }^{2}$ Growth rates calculated for the non-phosphatized layer were extrapolated through the phosphatized layers of the same crust sample.

The only method that consistently yielded estimated ages of initiation of growth for phosphatized crusts layers that are older than the age of phosphatization of those layers was the extrapolation of the growth rate of a non-phosphatized layer derived from the Equation of [29]. The only exception is sample RGR1_D10_003 L5-20, which contains a layer of ironstone material of unknown age in between the phosphatized and non-phosphatized crust generations, which means that an unknown time gap must be accounted for and that the age of 12.3 Ma will be older than indicated. Based on these data, the oldest estimated age of initiation of crust growth was about $47.8 \mathrm{Ma}$ for the thickest crust sample RGR1_D07_002, which included the estimate for the phosphatized portion (Figure 5).

\subsection{Growth Rate and Age of Initiation by $U$ and Th Isotopes}

The accretion rate of hydrogenetic Fe-Mn crusts can be estimated using U-Th geochronology following analytical and modeling procedures outlined by [51]. During crust formation, oxides incorporate an excess abundance of ${ }^{230} \mathrm{Th}$ derived from the ${ }^{234} \mathrm{U}$ decay dissolved in ocean water. This initial excess ${ }^{230} \mathrm{Th}$ decays with time to a ${ }^{230} \mathrm{Th}$ abundance that is controlled by the $\mathrm{U}$ content of the oxide. To simplify the model estimation of accretion rates, [51] calculated the "excess" ${ }^{230} \mathrm{Th}$ from accretion alone, not sourced from in situ ${ }^{234} \mathrm{U}$ decay and defined as ${ }^{230} \mathrm{Th}_{\text {excess }}$ (Supplementary Material Table S6). As the ferromanganese crusts grow, this ${ }^{230} \mathrm{Th}_{\text {excess }}$ decays to zero. Figure 6 presents the ${ }^{230} \mathrm{Th}_{\text {excess }}$ relative to ${ }^{232} \mathrm{Th}$ (which is stable on the timescales considered here) as a function of depth within-sample RGR1_D07_002. As predicted, the $\left({ }^{230} \mathrm{Th}\right.$ excess $\left./{ }^{232} \mathrm{Th}\right)$ decreases with depth reflecting decay of the initial excess ${ }^{230} \mathrm{Th}$. Note that brackets denote activity ratios. Estimates of the rate of crust accretion can be made using Equation (1) from [51]. The observed $\left({ }^{230} \mathrm{Th}_{\text {excess }} /{ }^{232} \mathrm{Th}\right)$ ratios from sample RGR1_D07_002 were consistent with modeled accretion rates of $1 \mathrm{~mm} / \mathrm{Myr}$ and lie between a range of $0.5-2.5 \mathrm{~mm} / \mathrm{Myr}$ (Figure 6), which is consistent with the growth rate derived from the Co-chronometer using the equation of Manheim and Lane-Bostwick (1988) and in good agreement with the $0.5-3.0 \mathrm{~mm} / \mathrm{Myr}$ rates of non-phosphatized Fe-Mn crusts from the São Paulo Plateau determined by the ${ }^{187} \mathrm{Os} /{ }^{188} \mathrm{Os}$ method [12]. It is important to use more than one method for determining crust growth rates and ages more accurately, as described by [52].

If the faster estimated growth rate of $2.5 \mathrm{~mm} / \mathrm{Myr}$ was extrapolated to the rest of the sample RGR1_D07_002, some phosphatized Fe-Mn layers yield ages of initiation younger than the age of phosphatization (Figure 5), which is not possible. On the other hand, if the slower estimated growth rate of $0.5 \mathrm{~mm} / \mathrm{Myr}$ was used, the age of crust initiation (110 Ma) was older than the age of RGR itself, which is also unrealistic. However, when the estimated growth rate of $1 \mathrm{~mm} / \mathrm{Myr}$ was extrapolated to the thickest $(9 \mathrm{~mm}$ ) non-phosphatized layer of RGR1_D07_002, the resulting estimated age of $9 \mathrm{Ma}$ was consistent with the age of phosphatization of the underlying layer (9.6 Ma), and the entire sample 
would have an estimated age of about $55 \mathrm{Ma}$ for initiation of crust growth, roughly comparable with the estimated Co-chronometer age of $48 \mathrm{Ma}$.

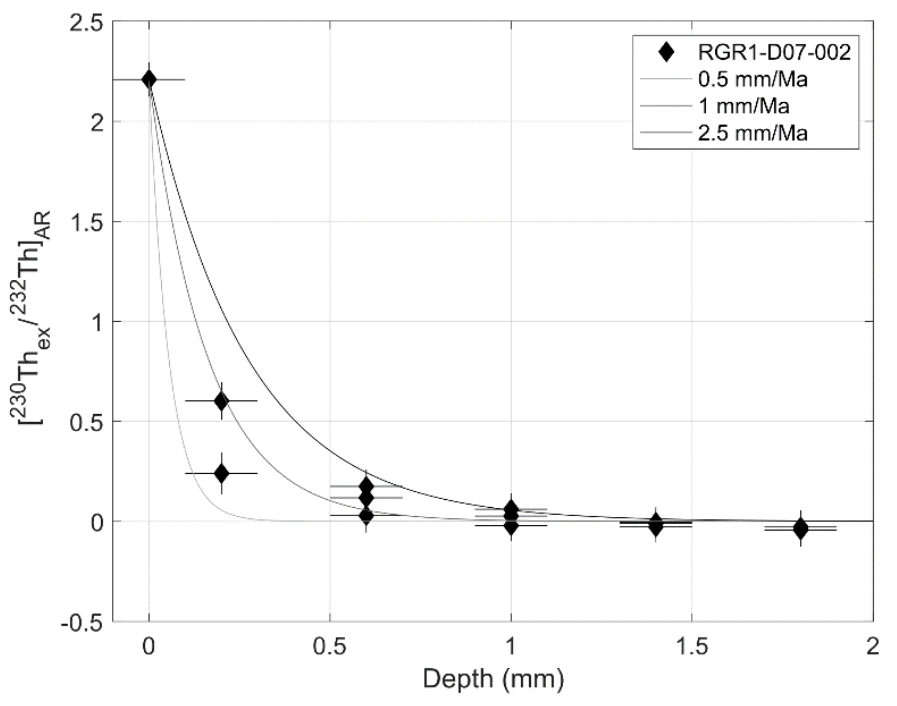

Figure 6. Observed ${ }^{230} \mathrm{Th}_{\text {excess }}{ }^{232} \mathrm{Th}$ ratios with depth in sample RGR1_D07_002 and modeled accretion rates of $0.5,1$, and $2.5 \mathrm{~mm} / \mathrm{Myr}$.

\section{Discussion}

\subsection{Two Generations of Fe-Mn Crusts on Rio Grande Rise}

Apart from the Fe-Mn crust samples from the central valley slope (dredge D02), typical structures, textures, and mineralogy of Fe-Mn crusts from RGR revealed two different crust generations (Figure 5). The first generation comprised of the major portion of the crusts and was capped by a thin 1-10 mm-thick second generation. The first generation was marked by CFA impregnation and accumulation of biogenic material, while the second crust generation grew after the phosphatization events and when biogenic particle accumulation decreased. In some samples, the first generation was the only one present and the lack of the second generation suggests that it was eroded by the strong currents that impacted the RGR plateau. Eroded botryoids of the top surface of the second generation in some samples corroborated this erosional process. Bottom currents of more than $0.2 \mathrm{~m} / \mathrm{s}$ may be capable of eroding Fe-Mn crust surfaces [53]. The prevalence of columnar and mottled texture is related to a higher amount of biogenic particle input that constrains or interrupts the formation of laminations [54].

Although thick Fe-Mn crusts from many northwest and central Pacific seamounts also present two crust generations with an older phosphatized crust and a younger non-phosphatized crust [54-57], the phosphatization of the first crust generation of RGR is more pervasive and intense. The phosphatized older crust generations from the Pacific seamounts have P contents of up to 5.5\% [54,58,59]. The phosphatized crust generation from RGR has a mean P content of $5.3 \%$ and ranges up to $7.7 \%$. The CFA content of the first generation from Pacific crusts may be up to $30 \%$ but generally, makes-up less than $10 \%$ of the crystalline phases [54], while the RGR phosphatized crust generation contains generally $25 \%$ CFA but, is as high as 50\% in sample RGR1_D11_003.

In the Pacific, the influence of phosphatization was found to be strong above $2500 \mathrm{~m}$ water depth and decreases with depth as only minor phosphatization is found in crusts from 2800 to $4000 \mathrm{~m}$ depth [55]. The crusts in RGR are at 600-800 $\mathrm{m}$ water depths today and may have been even shallower at the time the first generation was impregnated with CFA before thermal subsidence of RGR and the oceanic crust $[17,60]$. The very shallow water depth may be an important key in the formation of strongly phosphatized crusts on RGR and elsewhere. Shallower crusts may be more phosphatized because they experience higher phosphate concentrations during phosphatization than deeper crusts, and they may contain higher amounts of carbonate debris that can be easily replaced by CFA since they are 
closer to primary productivity and associated biogenic particle flux. Similar mixed Fe-Mn phosphorite pavements occur along the Blake Plateau in the northwest Atlantic Ocean [61] at comparable depths (500-800 m).

The fact that the crust samples from dredge D02 from the slope at about $825 \mathrm{~m}$ are not as phosphatized as the ones from the top of the plateau at $650-750 \mathrm{~m}$ indicates that local oceanographic variables, for example, the water depth and circulation, play a role in controlling the degree of phosphatization. The mineralogy of crust sample RGR1_D02_039 (15 mm-thick) from the slope shows that CFA was absent and $\mathrm{P}$ content was not higher than $0.48 \%$.

The formation of $10 \AA$ phyllomanganate in a Fe-Mn crust may occur due to the less-oxidizing conditions associated with phosphatization [56]. All the phosphatized generations of the crusts from the RGR plateau had a $10 \AA$ phyllomanganate phase, while only two out of 10 non-phosphatized crusts layers contained this phase.

\subsection{Chemical Composition of RGR Crusts Compared to Other Crusts}

\subsubsection{Recent Hydrogenetic Crust Formation}

The recent non-phosphatized Fe-Mn crusts ( $<10$ mm-thick) from the summit of RGR are typical hydrogenetic crusts and differ significantly from the bulk crusts. They mostly resemble crusts from the PCZ concerning Fe, Mn, Co, and total REY contents (Figure 7; Supplementary Material Table S7). However, they are remarkably enriched in $\mathrm{Mg}, \mathrm{Ca}, \mathrm{S}, \mathrm{As}, \mathrm{Bi}, \mathrm{Nb}, \mathrm{Ni}, \mathrm{Pb}, \mathrm{Te}, \mathrm{V}, \mathrm{Ce}, \mathrm{Rh}, \mathrm{Ru}$, and $\mathrm{Pt}$ compared in general to Fe-Mn crusts from the Atlantic, Indian, and South Pacific Oceans, the PCZ, and the California margin. Nevertheless, the RGR crusts are the most depleted in $\mathrm{Si}, \mathrm{K}$, and $\mathrm{Cu}$. The $\mathrm{Ca}$ and $\mathrm{Mg}$ enrichments are due to the high flux of planktonic foraminifera and nannoplankton tests. All of the elements mentioned can be related to biological productivity, through flux and dissolution of fine-grained carbonate and silica tests and frustules and release of sorbed metals, organic matter flux, and organic matter sorption of metals and release during oxidation. For example, $\mathrm{Nb}$ and $\mathrm{V}$ occur in foraminifera tests [62] for which the most delicate tests and fragments, as well as aragonite tests (i.e., Pteropods), would dissolve even at the relatively shallow-water depths of crusts in this study.

Many of the metals above have a nutrient-like distribution and are involved in biogeochemical processes in the water column. $\mathrm{Ni}$ is a nutrient-type metal that regenerates more rapidly than $\mathrm{Si}$ and $\mathrm{Cu}$ in the water column and, therefore, is made available in its dissolved form at shallower depth compared to the other two. This is especially evident by the increasing $\mathrm{Cu}$ content of crusts with an increasing water depth of crust formation [63]. Arsenic is another metal that has a nutrient-like vertical distribution in the ocean and its species and distribution are strongly controlled by biological processes in the water column [64]. Arsenate $\left(\mathrm{As}^{5+}\right)$ is taken up by phytoplankton at the surface to produce organic compounds and is regenerated at the base of the euphotic zone, having a low concentration in surface waters and maximum concentration in the subsurface with a peak at about $1000 \mathrm{~m}$ water depth [65]. Rhodium has a nutrient-type distribution and is enriched in pelagic sediments and marine phosphorites [66]. Dissolved V has a surface minimum concentration, associated with binding to organic particulate matter, which is rapidly remineralized, like phosphate [67]. In contrast, $\mathrm{Si}, \mathrm{Cr}$, and $\mathrm{Cu}$ are regenerated in deeper waters [68] as also are $\mathrm{Zr}$ and Hf [69]. Thus, the water depth of the RGR summit relative to the depth of regeneration of sinking particles seems to play a key role in the chemical composition of the crusts.

Other metals most enriched in the recent non-phosphatized crust had a scavenging-type behavior in the ocean-water column, i.e., their concentration was high at the surface and decreased with water depth. Their distribution was most similar to that of $\mathrm{Mn}$. $\mathrm{Ce}, \mathrm{Bi}, \mathrm{Pb}$, and Te have a scavenging-type distribution in the water column [70-73], and are regenerated at rather shallow depths $400 \mathrm{~m}$. The concentration of Te decreases with depth in the Angola Basin (South Atlantic; [71]). These scavenged metals should be available for sorption on crusts at the water depths of the RGR crusts. 


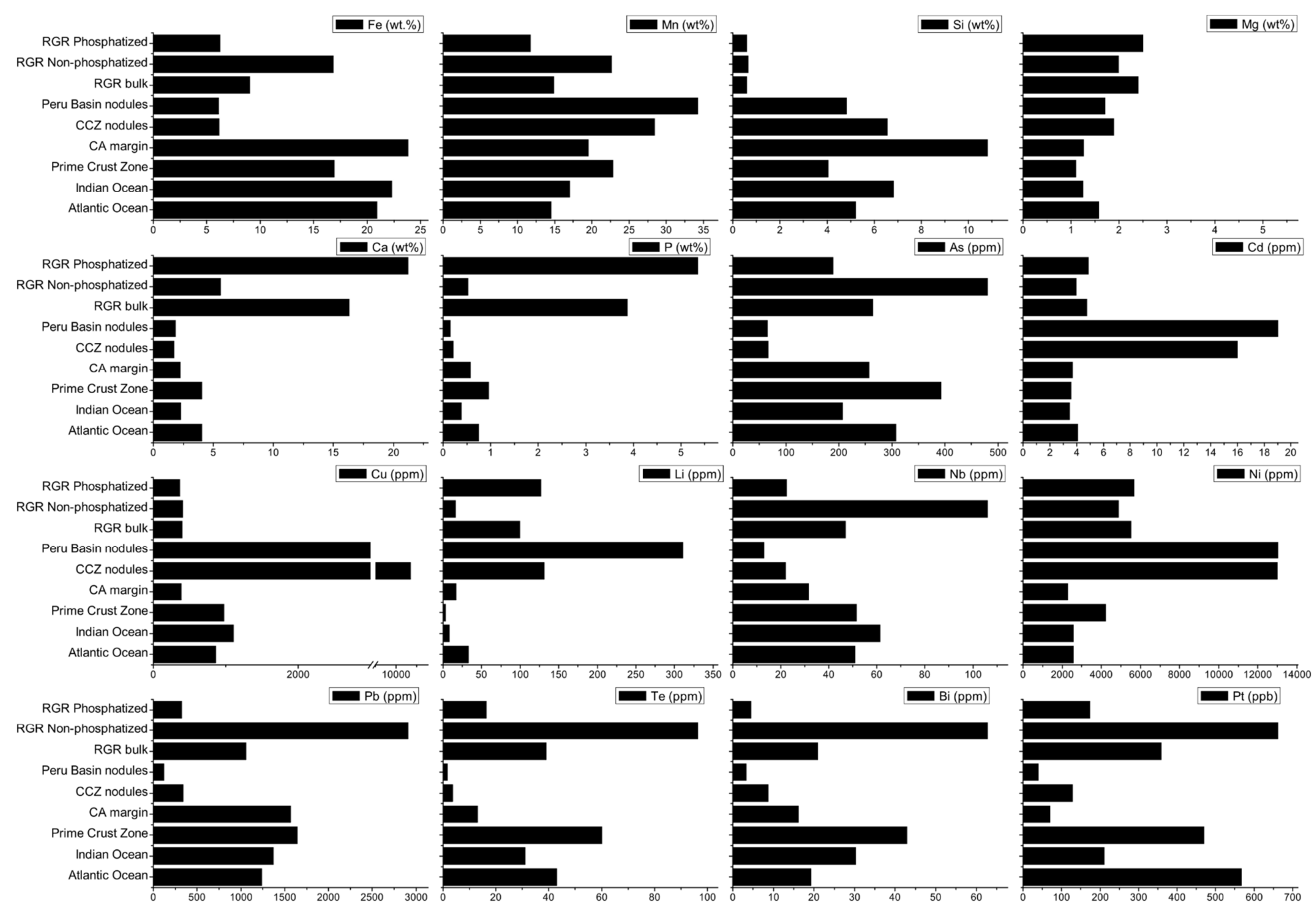

Figure 7. Comparison between the chemical composition of bulk, non-phosphatized Fe-Mn crusts, and phosphatized crusts from the RGR summit and Fe-Mn deposits formed elsewhere, compiled by [10] from [1]. Peru Basin nodules correspond to the diagenetic end-member. 
The vertical distribution of Pt contrasts in different oceans [74,75], however many stations across the southwestern Atlantic Ocean showed that a peak in Pt concentration at $800 \mathrm{~m}$ water depth occurs within the Antarctic Intermediate Water close to the location of RGR [76]. The content of most of the PGM in Fe-Mn crusts is inversely correlated with water depth [77], which may explain the high contents of Pt as well as Rh and Ru in RGR summit non-phosphatized crusts. Generally, Pt, Rh, and $\mathrm{Ru}$ are derived from the seawater, although $\mathrm{Ru}$ can also derive from detrital material [54].

Past studies on northeast Atlantic and Arctic Ocean Fe-Mn crusts found a strong terrigenous component (i.e., enrichments in $\mathrm{Fe}, \mathrm{Pb}, \mathrm{Al}$, and $\mathrm{Si}$ and a mean $\mathrm{Fe} / \mathrm{Mn}$ ratio of $>1.30$ ) in those crusts compared to Pacific Ocean crusts due to input by aeolian and fluvial transport [9,11,78,79]. In contrast, the lowest $\mathrm{Si}$ content and $\mathrm{Si} / \mathrm{Al}$ ratios occur in RGR summit crusts compared to crusts from elsewhere (Figure 7), indicating only minor terrigenous input. In that regard, the hydrogenetic crusts from the RGR summit are more similar to open-ocean Pacific seamount crusts [5].

In summary, dissolved Mn contents are controlled mainly by oxygen concentration in ocean water and are higher in crusts from shallower less-oxygenated waters $[54,63,80]$. The crusts from the RGR summit are a good example of shallow-water type, Mn-rich crusts from the Atlantic Ocean. An important source of metals to the younger generation, non-phosphatized crusts is related to biological productivity. However, more than that, the rate of regeneration of metals carried by biogenic particles (both labile and refractory) plays a key role in the RGR crust chemical composition. Ultimately, the rate of remineralization dictates the availability of the dissolved form of metals related to biological productivity and the degradation of those products, which are then available for sorption by crust oxide minerals. Secondly, the depth of RGR crusts also enables them to receive dissolved metals from aeolian sources, which because of scavenging in surface waters would not be as available to crusts formed in deeper waters. Therefore, younger generation RGR crust formation is a result of an optimal depth of availability of metals in ocean water from scavenging distribution ( $\mathrm{Bi}, \mathrm{Pb}, \mathrm{and} \mathrm{Te})$ and nutrient-type distribution with rapid regeneration (As, $\mathrm{Ni}$, and $\mathrm{V}$ ).

\subsubsection{Influence of Phosphatization on the Chemical Composition of RGR Crusts}

Several processes are known to have altered the mineralogy and chemical composition of hydrogenetic Fe-Mn crusts in the Pacific and Indian Oceans during phosphatization. For example, the replacement of carbonate, replacement of Fe oxyhydroxides preferentially over Mn oxides, alteration of the Mn oxide, and precipitation of CFA in pore spaces have been observed [55,81,82]. Here, we show that these secondary processes also acted in changing the chemical composition and mineralogy of originally hydrogenetic RGR summit Fe-Mn crusts.

The decrease of the Fe/Mn ratio from non-phosphatized crusts (mean 0.7) to phosphatized crusts (mean 0.5) for RGR summit crusts was consistent with the preferential replacement of the Fe oxyhydroxides preferentially over Mn oxides during phosphatization. The Si/Al ratios decreased from 0.7 to 0.4 , which might have resulted from the preferential replacement of Si-rich phases over Al-rich phases, Si adsorbed onto Fe oxyhydroxides, or bio-silica [6].

The phosphatized generation of RGR crusts had lower contents of most elements compared to the non-phosphatized generation (Figure 8). All of these metals are hosted by the Fe oxyhydroxide or both the Fe and Mn phases (e.g., Te) in the non-phosphatized crust and their decrease in the phosphatized crusts are consistent with a loss of part of the Fe phase [55].

Elements not associated with the CFA should have contents reduced because of dilution by diagenetic CFA formation. However, the enrichment in $\mathrm{Ni}$ and $\mathrm{Zn}$, elements that are typically associated with the Mn phase and not the CFA, means that these elements increased over the dilution process, although the content of their predominant host, Mn, did not. This may be due to the diagenetic alteration of the vernadite to the $10 \AA$ phyllomanganate during the formation of CFA under suboxic conditions, promoting the acquisition of more $\mathrm{Ni}^{2+}$ and $\mathrm{Zn}^{2+}[6,83]$. Ni, together with $\mathrm{Cu}$ and $\mathrm{Zn}$, become enriched in crusts that have been phosphatized $[6,11]$ because these cations are accommodated in the structure of $10 \AA$ manganates [84]. Cu and Zn do not accompany the remarkable enrichment of 
$\mathrm{Ni}$ in crusts from RGR, and their content is equal to or even lower than in crusts from elsewhere. This difference may be explained by the different rates of remineralization with water depth for $\mathrm{Ni}, \mathrm{Cu}$, and $\mathrm{Zn}$, as discussed previously. The Ni vertical distribution most resembles that of the nutrients $\mathrm{NO}_{3}$ and $\mathrm{PO}_{4}$, which regenerate more rapidly, while the vertical distribution of $\mathrm{Zn}$ and $\mathrm{Cu}$ most resembles that of $\mathrm{Si}$, which regenerates more slowly in the water column [85-87].

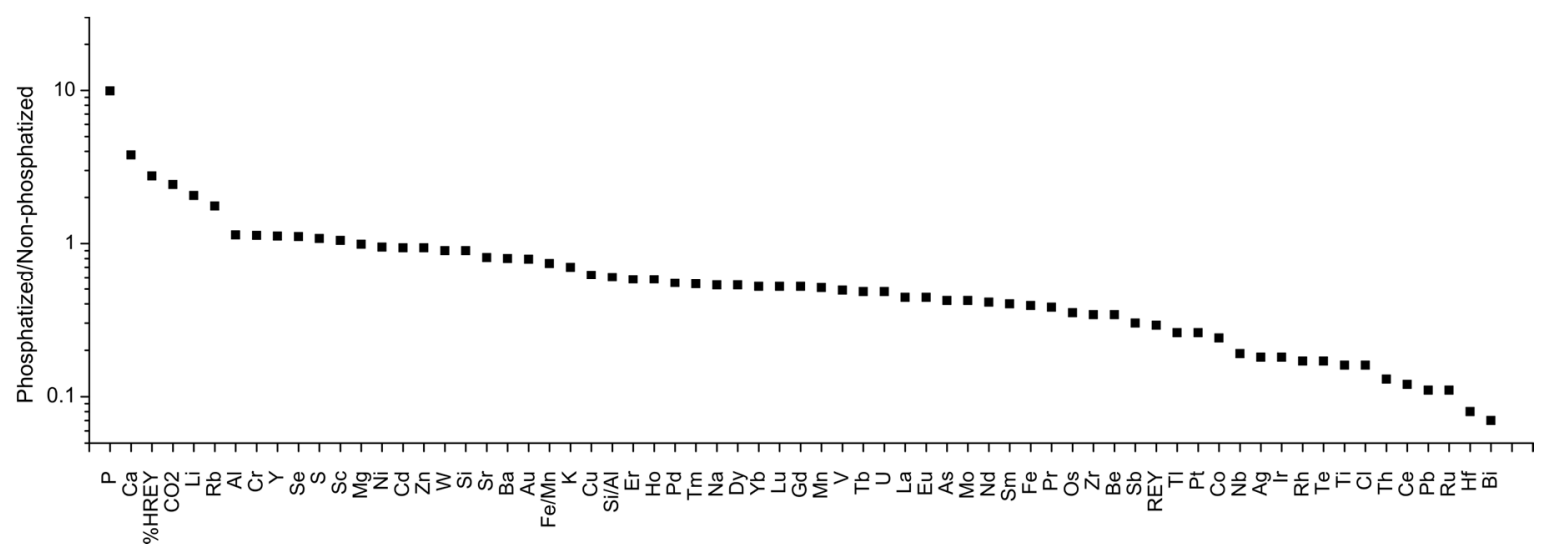

Figure 8. Element enrichment for mean phosphatized $(n=16)$ and mean non-phosphatized $(n=6)$ generations of crusts from the Rio Grande Rise. Elements above the line are enriched in the phosphatized generation, while elements below the line are enriched in the non-phosphatized generation.

The same similarity with $\mathrm{NO}_{3}$ and $\mathrm{PO}_{4}$ distribution occurs with $\mathrm{Cd}[86,88,89]$. Cd and its isotopes are a proxy for biological productivity $[90,91]$. The enrichment in $\mathrm{Cd}$ contents in the phosphatized RGR crusts suggests a high input of biological material. Additionally, Cd enrichment in phosphatized crusts from the Ninetyeast Ridge in the Indian Ocean was suggested to reflect the replacement of $\mathrm{Cd}^{2+}$ for $\mathrm{Ca}^{2+}$ in the CFA due to their similar ionic radius [49].

Aluminum enrichment is unexpected since it usually shows a strong depletion in phosphatized crusts [55]. The aluminum content of seamount phosphorites increases with increasing biogenic silica [49] since Al is a component of silica frustules of diatoms in variable amounts [92]. In this case, we would expect an enrichment of $\mathrm{Si}$ in the phosphatized crust of equal magnitude as $\mathrm{Al}$, which is not found because the Si phases likely underwent replacement preferentially over Al phases during phosphatization [55]. Besides, there is only a weak correlation between $\mathrm{Al}$ and Si. A high Al content decoupled from terrigenous particle flux can be associated with the removal of $\mathrm{Al}$ from ocean water by settling biogenic particles [93]. The correlations between $\mathrm{Al}$ and elements that have nutrient-type distribution in the water column, $\mathrm{Cd}, \mathrm{Cu}$, and $\mathrm{Ni}$ support this hypothesis.

As for $\mathrm{Li}$, its enrichment of manganese nodules has been associated with a source from diagenetic reactions in the sediment and the presence of $10 \AA$ manganates as a host for the Li (e.g., [1,94]). The $10 \AA$ manganates can incorporate high amounts of $\mathrm{Li}$ into their structure, while $\delta-\mathrm{MnO}_{2}$ can only adsorb small amounts of Li. Further, it has been suggested that Li can be inherited from planktonic tests and adsorbed onto CFA [49]. In that regard, the high Li enrichment in the phosphatized RGR crusts can also be due to the high accumulation of foraminifera tests during crust growth and incorporation of Li from diagenetic reactions during phosphatization, which occurs in a suboxic environment.

Sulfate $\left(\mathrm{SO}_{4}\right)$ substitutes for phosphate $\left(\mathrm{PO}_{4}\right)$ in the apatite structure $[95,96]$, which is consistent with the correlation between S and P at the 99\% CL (Supplementary Material Table S4). Substitution might also be the reason for HREY enrichments. Yttrium $\left(\mathrm{Y}^{3+}\right)$ and the $\mathrm{REE}^{3+}$ replace $\mathrm{Ca}^{2+}$ in the $\mathrm{CFA}$ structure [49,96], which is consistent with the positive correlation between the REY (excepting Ce) and P, especially for Y. [49] found that the \%HREY of the total REY complement from seamount phosphorites is higher than in associated Fe-Mn crusts, due to different mechanisms of REE incorporation. While REE are sorbed by the Fe-Mn oxyhydroxides, they predominantly replace Ca in the CFA structure, and this process is favored for the HREE $[49,96]$. Additionally, a strong complexation exists between 
REE and carbonate in ocean water, which increases with the increasing atomic number of the REE and which can be inherited by the CFA. However, the idea that phosphatized crusts are more enriched in REY compared to non-phosphatized crusts because of the presence of CFA [49,54] is not true for phosphatized crusts from the RGR. This might be due to the shallower water depth of crust formation at RGR since dissolved REY concentrations in ocean water tend to increase with increasing water depth [97,98]. Besides, the lower REY can be due to younger ages of the RGR CFA, since aging phosphorites allow for enrichment in REY over time [49].

In summary, the chemical composition of Fe-Mn crusts from the summit of RGR was affected during phosphatization due to the precipitation of CFA, loss of part of the Fe phase, alteration of part of the Mn phase, and incorporation of metals from biological productivity, with some of them probably hosted by a diagenetic $10 \AA$ phyllomanganate.

\subsubsection{Bulk Crusts}

As a result of the remarkable degree of phosphatization, bulk Fe-Mn crusts from the summit of RGR have quite different chemical composition compared to crusts from elsewhere. They contain the lowest Fe contents and Fe/Mn ratios and the highest $\mathrm{Ca}$ and P contents (Figure 7; Supplementary Material Table S7). Ca and P are enriched in RGR crusts four and five times, respectively, over crusts from the Atlantic Ocean, four times compared to PCZ crusts, and seven times over California margin crusts. RGR crusts are the most enriched in $\mathrm{Ni}$ and $\mathrm{Li}$, in which the concentrations are just somewhat less than that of mixed-type CCZ manganese nodules and diagenetic end-members Peru Basin manganese nodules (Figure 7). Bulk RGR crusts are remarkably enriched in Li, 36 times over PCZ crusts, six times over crusts from the California margin, and three times over Atlantic Ocean crusts (Figure 7; Supplementary Material Figure S4). HREE are most enriched in RGR Fe-Mn crusts (average 50 ppm; Figure 7). The \%HREY complement of the total REY complement was three times higher in the RGR crusts compared to PCZ crusts and four times over California margin and Atlantic Ocean crusts. Total REY and individual REE concentrations were depleted in crusts from RGR compared to crusts from elsewhere, except $Y$.

RGR summit bulk crust Ca and P contents of $16.6 \%$ and $3.94 \%$ respectively are higher than those of phosphatized crusts from other regions, for example, the Ninetyeast Ridge in the Indian Ocean, 3.38\% Ca and 0.82\% P [6] and the Tricorn Seamount, Pacific Ocean, 11.0\% Ca and 3.7\% P [8], which also have an older phosphatized crust generation. Those differences are likely in part because crusts from RGR formed at shallower water depths (700-800 m) compared to crusts from Tricorn seamount and Ninetyeast Ridge, 1100 and 2000 m, respectively. There are also likely differences in primary productivity in these three areas.

In general, the chemical composition of bulk RGR crusts was controlled by high biological productivity for most of the history of crust growth, and also to the growth of RGR crusts at relatively shallow water depths so that nutrient-type elements with rapid regeneration were readily available. Additionally, the strong phosphatization and formation of diagenetic CFA under suboxic conditions in the crusts were a major control of RGR crust composition as there has been a loss of most of the non-phosphatized crust generation to current erosion for RGR summit crusts.

\subsubsection{Anomalous Diagenetic-type Fe-Mn Crust}

The anomalous Li-Ni-rich sample RGR1_D10_002 (Figure 2e) had Li and Ni contents (330 ppm and $1.10 \mathrm{wt} \%$, respectively) as high as the diagenetic Mn nodule end-member from the Peru Basin, which has a mean of $310 \mathrm{ppm} \mathrm{Li}$ and $1.30 \mathrm{wt} \% \mathrm{Ni}$ [35]. Additionally, like the Peru Basin nodules, this sample contains $10 \AA$ manganate, which is a diagenetic phase and accommodates large amounts of divalent cations like $\mathrm{Ni}, \mathrm{Cu}$, and $\mathrm{Zn}$ [1]. In this anomalous sample, a fractionation between $\mathrm{Ni}$ and $\mathrm{Cu}$ occurs. This is a unique feature of the diagenetic Peru Basin nodules, which had an Mn/Fe ratio of 5.56 and characterized the diagenetic end-member nodules (Figure 7). However, the Mn/Fe ratio of sample RGR1_D10_002 was 2.3, and its large $\mathrm{Ce}_{\text {sn }}$ anomaly of 3.79 (Figure 9) suggests that this sample formed 
under oxic conditions. Crusts and nodules formed under oxic conditions but influenced by diagenetic reactions were studied from Shatsky Rise, NW Pacific, where $\mathrm{Cu}-\mathrm{Ni}$-Li-rich crusts with an $\mathrm{Mn} / \mathrm{Fe}$ of 2.0 formed under redox conditions not low enough to form $10 \AA$ manganate [99]. Shatsky Rise crusts have Ni and Li contents lower than in RGR crust RGR1_D10_002. With the somewhat higher Mn/Fe ratio of RGR sample RGR1_D10_002 in, redox conditions were low enough to have a $10 \AA$ manganate form, accommodating more $\mathrm{Ni}^{2+}$ and $\mathrm{Li}^{+}$cations, but not $\mathrm{Cu}^{2+}$, compared to Shatsky Rise crusts. The fractionation between $\mathrm{Ni}$ and $\mathrm{Cu}$ can be explained by the rate of regeneration in the water column discussed above, especially evident at RGR since crust RGR1_D10_002 was collected from $680 \mathrm{~m}$ water depth, whereas the Shatsky Rise crusts formed at $4000 \mathrm{~m}$. However, this does not fully explain the Ni and Li enrichments and formation of $10 \AA$ manganate in one sample and not in the other non-phosphatized crusts. The water depth is also the reason for Li enrichment in crusts from Shatsky Rise because Li was derived from carbonate dissolution since the highest contents of Li were found in crusts that formed close to the CCD. Lithium is present in foraminifera tests [100], and foraminifera are the dominant component of sediments along RGR. The substrate for sample RGR1_D10_002 is a lithified foraminiferal sand. Although the RGR summit is much shallower than the CCD, the more delicate carbonate tests may have been dissolved in the water column or microenvironments in the sediment and then the released elements incorporated into the $10 \AA$ manganate.
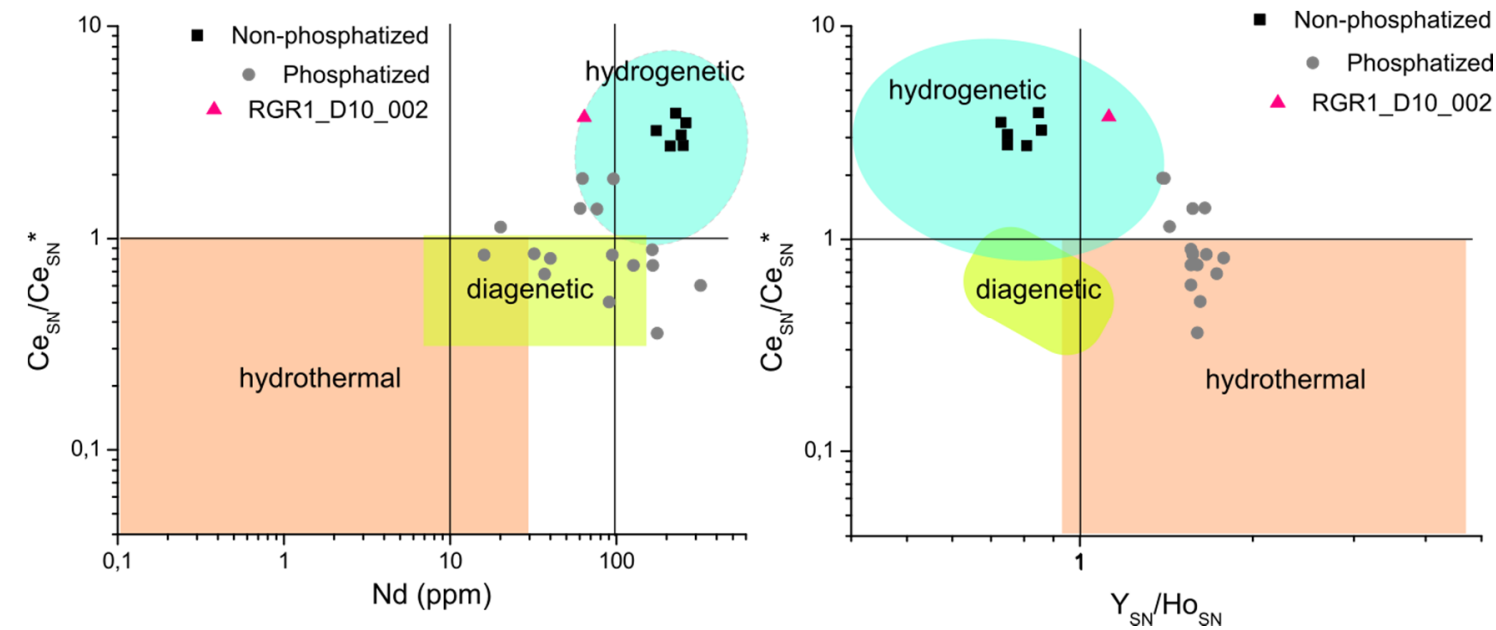

Figure 9. Discrimination diagrams of $\mathrm{Ce}_{\mathrm{SN}} / \mathrm{Ce}_{\mathrm{SN}}{ }^{*}$ ratio vs. $\mathrm{Nd}$ concentration (left) and $\mathrm{Ce}_{\mathrm{SN}} / \mathrm{Ce}_{\mathrm{SN}}{ }^{*}$ ratio vs. $\mathrm{Y}_{\mathrm{SN}} / \mathrm{Ho}_{\mathrm{SN}}$ (right) from [101] for non-phosphatized, phosphatized, and anomalous non-phosphatized sample RGR1_D10_002 Fe-Mn crusts from the Rio Grande Rise.

Different from the other samples, the non-phosphatized crust RGR1_D10_002 grew completely around the substrate rock and the studied side may not correspond to the top exposed directly to ocean water but rather to the crust on one of the sides or the bottom of the encrusted rock. Crusts that likewise grow on the sides and bottom of a sample may reflect different redox conditions thereby producing different growth rates; this process has been found, for example, to increase Co contents in Pacific seamount crusts that grew on the sides of thick crusts [54]. This environmental control may decrease or increase redox-sensitive metals in different parts of the crusts. Another different aspect from the other samples is that the substrate rock is a phosphatized foraminifera sandstone and, therefore, experienced diagenesis under suboxic conditions. Although the formation of the non-phosphatized crust requires that the substrate had already been phosphatized before crust formation, it may have influenced the crust formation in microenvironments. For example, the substrate phosphorite is impregnated with Mn oxides showing potential exchange with the crust (Figure 2e). The formation of this anomalous sample may be a combination of processes mentioned in addition to the position of the crust relative to the substrate and the seabed, as well as diagenetic reactions within the substrate. No other sample 
from dredge D10, or other dredges relatively close to D10, are similar to RGR1_D10_002, so it seems that this unique sample is the specific result of local characteristics of the depositional environment.

\subsection{REY Patterns and the Genesis of RGR Crusts}

$\mathrm{REY}_{\mathrm{sn}}$ patterns are commonly used to distinguish the origin of different types of marine precipitates; hydrogenetic, diagenetic, hydrothermal, and mixed origins will show different $R E Y_{\mathrm{sn}}$ configurations [101]. The REY $\mathrm{Sn}_{\mathrm{sn}}$ patterns of RGR Fe-Mn crusts are distinct for the non-phosphatized and phosphatized generations and reflect the fundamental formation and post-depositional processes. The REY ${ }_{\text {sn }}$ curves for the RGR non-phosphatized crusts are typical for hydrogenetic Fe-Mn crusts [101], with an overall flat pattern with strong positive $C_{e_{s n}}$ anomalies and negative $Y_{\text {sn }}$ anomalies (Figure 10). On the other hand, the REY sn patterns of the phosphatized crusts from RGR show an increasing trend from $\operatorname{Pr}$ to $\mathrm{Y}$, and a slight decreasing trend to $\mathrm{Lu}$, and with large positive $\mathrm{Y}_{\mathrm{sn}}$ anomalies, small positive $\mathrm{Gd}_{\mathrm{sn}}$ anomalies, and variable but mostly negative $\mathrm{Ce}_{\mathrm{sn}}$ anomalies (Figure 10).

The positive $\mathrm{Ce}_{\mathrm{sn}}$ anomaly in hydrogenetic crusts is due to the oxidative scavenging of Ce from seawater by the Fe-Mn (oxyhydr)oxides, and its intensity is related to the time of exposure of the Fe-Mn (oxyhydr)oxides to seawater (the growth rate; $[47,101,102])$. Therefore, the large positive $\mathrm{Ce}_{\mathrm{sn}}$ anomaly in RGR non-phosphatized crusts reflects slow growth rates of about $1 \mathrm{~mm} / \mathrm{Myr}$ as determined here by U-series dating. The negative $\mathrm{Ce}_{\mathrm{sn}}$ anomalies characterize crusts with abundant CFA [103] and it is a feature of seamount phosphorites that reflect the negative Ce anomaly in ocean water and the suboxic conditions under which phosphatization occurred [49,102]. This is accompanied by a mean Ce concentration that increases from 303 ppm in the phosphatized crusts to 1287 ppm for the non-phosphatized crusts. This way, the variable $\mathrm{Ce}_{\mathrm{sn}}$ anomaly of the phosphatized crusts from RGR reflects the different degrees of phosphatization. Variable $\mathrm{Ce}_{\mathrm{sn}}$ anomalies are also characteristic of phosphatized crusts from the Ninetyeast Ridge in the Indian Ocean [6].
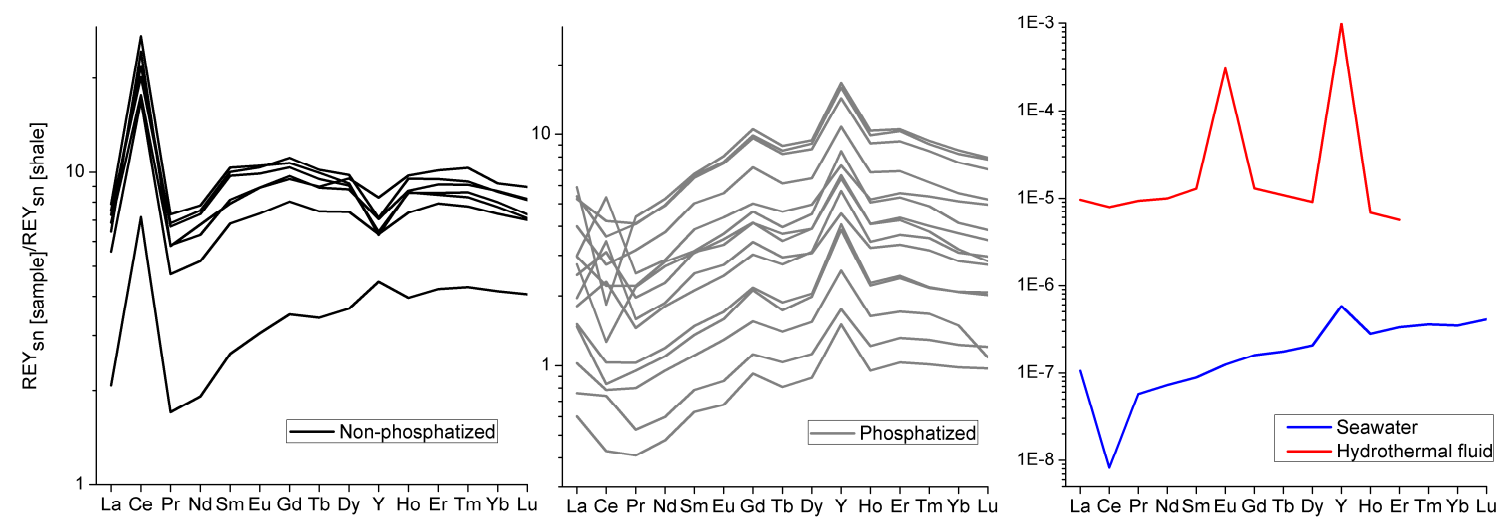

Figure 10. Post Archean Australian Shale (PAAS)-normalized rare earth elements plus yttrium plots for bulk and layers of RGR non-phosphatized (left), phosphatized Fe-Mn crusts (middle), and of hydrothermal fluid from mid-ocean ridges (red; from [104], and seawater at $800 \mathrm{~m}$ water depth from offshore Japan (blue; from [73]).

The negative $\mathrm{Y}_{\mathrm{sn}}$ anomaly in hydrogenetic crusts strongly contrasts with that of seawater and is due to the preferential scavenging of $\mathrm{Y}$ and its geochemical twin Ho by the hydrogenetic (oxyhydr)oxides, since Y generates surface-complexes of lower stability [101,102]. This does not happen to CFA or carbonates, which tend to reflect the typical $R E Y_{\text {sn }}$ pattern of seawater with a positive $Y_{\text {sn }}$ anomaly (Figure 10; $[49,102])$. Additionally, the overall depletion of individual $R E Y_{\mathrm{sn}}$ in the phosphatized crust from RGR, except for $Y_{s n}$, increases the fractionation with adjacent REY elements and makes a more accentuated $\mathrm{Y}$ anomaly. This is especially clear from the high mean $\mathrm{Y} /$ Ho ratios (43), close to that of seawater [6,102], and low mean Y/Ho ratios of non-phosphatized layers (23). 
A hydrothermal influence is suspected to have occurred during RGR crusts formation due to the presence of the ironstone layers [105,106], pyrolusite occurrence in one sample [46], high Li and $\mathrm{Ni}$ contents [107], the presence of $10 \AA$ manganates [78], and the low Fe/Mn ratios. However, all of those characteristics described above can have alternative explanations as discussed earlier in this paper. Besides, the absence of a positive $\mathrm{Eu}_{\mathrm{sn}}$ anomaly and lack of evidence of volcanic activity in the RGR for the past $46 \mathrm{Myr}$ does not favor a hydrothermal contribution to the crusts from RGR, although it cannot be excluded for the older parts of thick crusts. A high $(\mathrm{Fe}+\mathrm{Mn}) / \mathrm{Ti}$ ratios (in the $100 \mathrm{~s}$ ) has been attributed to the influence of hydrothermal fluids in Fe-Mn crust formation on some Atlantic Ocean seamounts [78]. Sample RGR1_D05_011, which contains pyrolusite and ironstone layers, has a $(\mathrm{Fe}+\mathrm{Mn}) / \mathrm{Ti}$ ratio of 588 . Thus, the influence of hydrothermal input to some Fe-Mn crusts cannot be excluded.

The REY genetic discrimination diagram (Figure 9) shows that the non-phosphatized layers of RGR Fe-Mn crusts plot in the hydrogenetic area as expected, except RGR1_D10_002, the outlier sample described above. The diagram was not designed for phosphatized samples [101]. The hydrogenetic origin of the Fe-Mn crusts from RGR is also evident from the $10^{*}(\mathrm{Cu}+\mathrm{Ni}+\mathrm{Co}) v \mathrm{~s} .100^{*}(\mathrm{Zr}+\mathrm{Y}+$ $\mathrm{Ce})$ vs. $(\mathrm{Fe}+\mathrm{Mn}) / 4$ ternary diagram proposed by [108] (Figure 11), in which the phosphatized crusts and the anomalous non-phosphatized sample RGR1_D10_002 predominantly plot along a mixing line between the hydrogenetic and diagenetic fields. This is in agreement with the post-depositional alteration of Fe-Mn crust during phosphatization. Perhaps a mixing with a hydrothermal component exists in a few samples.

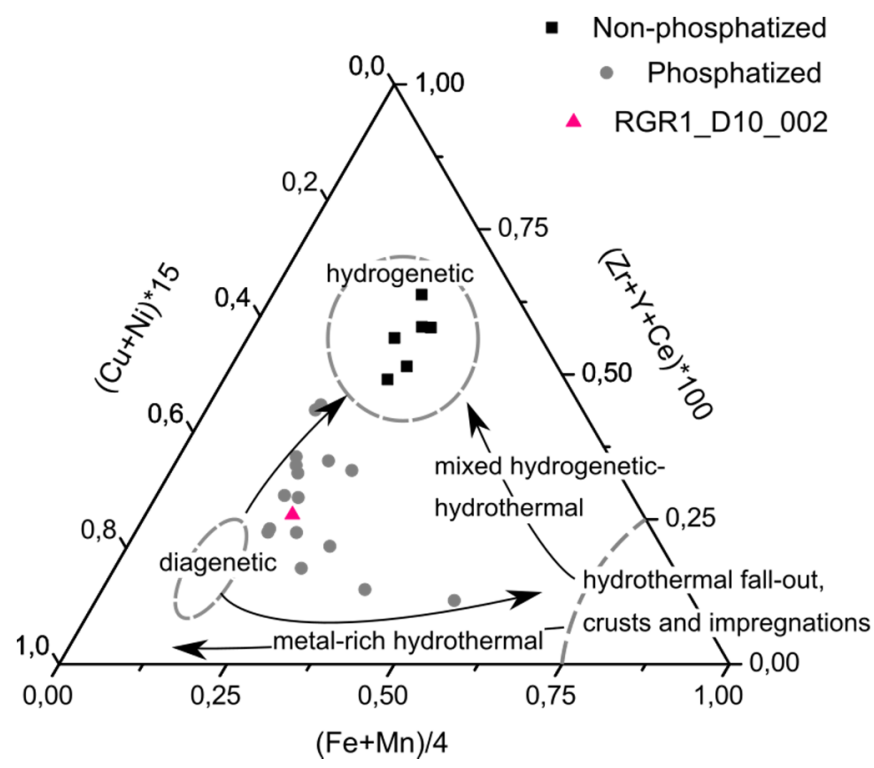

Figure 11. Discrimination diagram based on the content of major (Fe and $\mathrm{Mn}$ ), trace ( $\mathrm{Cu}$ and $\mathrm{Ni}$ ), and high field strength and rare earth elements (Zr, Y, and Ce) from [108]. Non-phosphatized Fe-Mn crusts from RGR fall within the hydrogenetic field, while phosphatized Fe-Mn crusts and the anomalous non-phosphatized RGR1_D10_002 tend to the diagenetic field.

\subsection{History of Phosphatization of $\mathrm{Fe}-\mathrm{Mn}$ Crusts on the Summit of RGR}

The first phosphatization episode that affected Fe-Mn crusts from the summit of RGR as determined by CFA extracted from the crusts occurred from about 20 to $15 \mathrm{Ma}$ (Figure 12). This is consistent with a large global phosphatization episode at the Oligocene-Early Miocene boundary (between 27 and $21 \mathrm{Ma}$ ) that affected seamounts distributed globally $[81,109]$. This major event was associated with global change in the ocean system, probably a transition from warm water and sluggish circulation to the establishment of cold water and thermohaline overturning circulation [110]. Ultimately, this resulted in the cycling of nutrients and especially phosphorus through increased upwelling [55]. 
A study based on planktonic foraminifera accumulation rates in an Oligocene-Early Miocene section of a sediment core from RGR shows an increased sedimentation rate and paleoproductivity between 23.9 and 22.9 Ma, with the highest rates at the Oligocene-Miocene boundary (23.3 Ma), followed by an immediate decrease of both sedimentation rates and paleoproductivity [111]. An enrichment of biogenic silica input to sediments also occurred during the late Oligocene and Early Miocene [112]. This first RGR phosphatization age range also coincides with a minor event at 15 Ma identified for Pacific seamounts, where it is separated from the late Oligocene-Early Miocene episode by an interval of no phosphatization [81]. Equatorial East Atlantic reef limestones were phosphatized in the Early Miocene with ages between 23 and $16 \mathrm{Ma}$ [113], suggesting that in the Atlantic, other regional processes acted to extend this episode of phosphatization. For example, the near continental-margin location of the bank studied by [113] was more subject to consistent upwelling, typical of continental margins like offshore Peru and California.

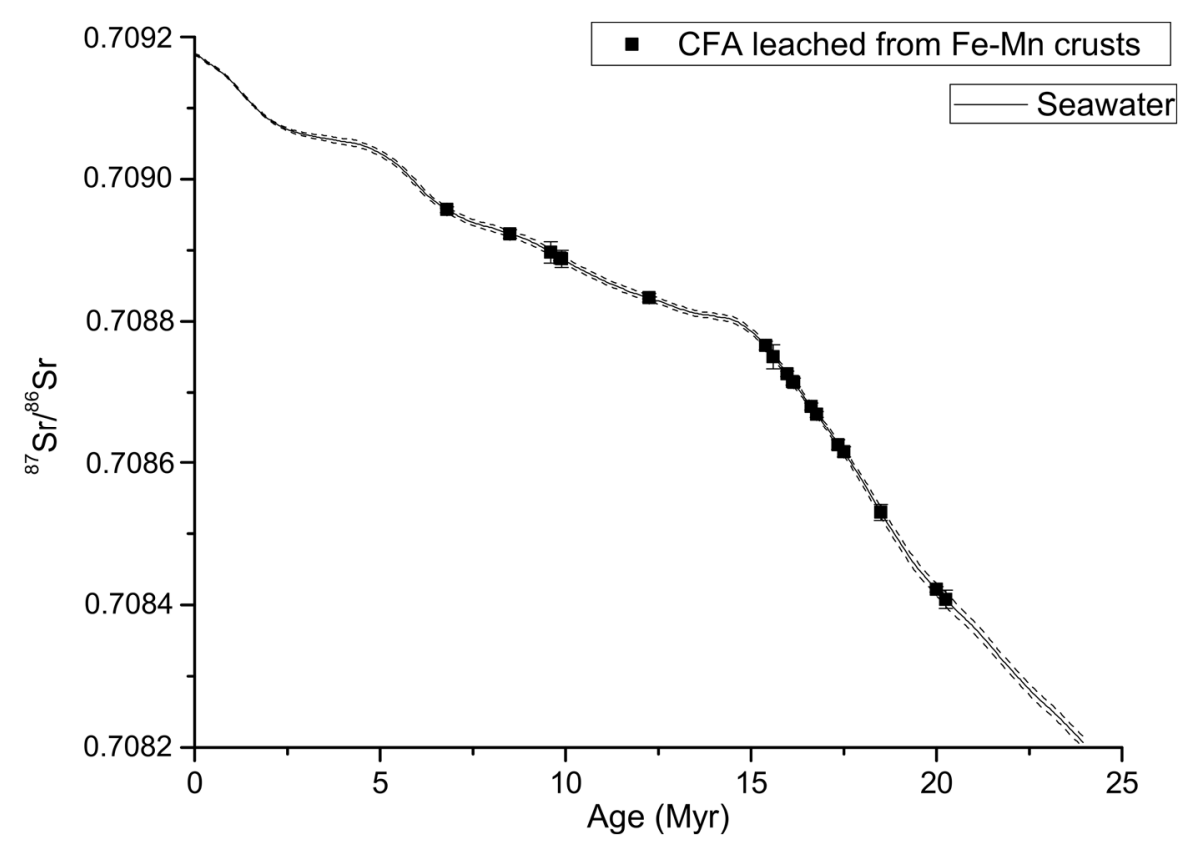

Figure 12. ${ }^{86} \mathrm{Sr} /{ }^{87} \mathrm{Sr}$ isotopic ratio of seawater (gray line) and CFA leached from phosphatized Fe-Mn crusts from the Rio Grande Rise.

Younger crust phosphatization events occurred along the RGR summit from 10 to $6.8 \mathrm{Ma}$ (Figure 12), with no parallel in Pacific seamount rocks, but possibly coincides with phosphorites in the equatorial eastern Atlantic dated as $6 \mathrm{Ma}$ [113].

Organic carbon maxima in sediments from Deep Sea Drilling Project (DSDP) Site 516 in the RGR [18] coincide well with ages determined by magnetobiostratigraphy of 19.09 Ma and 15.5 Ma [114]. These organic carbon peaks reflect enhanced biological productivity in surface waters that exported high amounts of $\mathrm{P}$ to the RGR seabed that likely facilitated the phosphatization.

\subsection{The Role of Surface Biological Productivity in RGR Fe-Mn Crust Formation}

The biorelated elements ( $\mathrm{Ni}, \mathrm{Zn}, \mathrm{As}$, and $\mathrm{Cd}$ ) that are particularly enriched in RGR crusts make them unique in the global ocean and suggest an important source of metals from biological productivity to Fe-Mn crusts forming along the RGR summit in well-oxygenated waters in the recent past (post $6 \mathrm{Ma}$ ). Modern oceanographic conditions at RGR suggest that both local primary productivity and advection of nutrients by water masses play important roles in supplying nutrient-type metals $(\mathrm{Ni}$, $\mathrm{Zn}, \mathrm{As}$, and $\mathrm{Cd}$ ) to recent $\mathrm{Fe}-\mathrm{Mn}$ precipitation, but these conditions cannot be extrapolated to tens of millions year of Fe-Mn crust formation. Nevertheless, periods of enhanced biological productivity 
occurred in the past above RGR producing suboxic conditions and supplying the phosphate to seawater that facilitated phosphatization.

Fe-Mn crusts from the RGR summit today are forming above the OMZ, bathed by the oxygenated Antarctic Intermediate Water (AAIW) and below the less oxygenated South Atlantic Mode Water (SAMW; Figure 13). The SAMW forms by sinking of nitrate-rich Si-depleted surface water at high latitude in the Southern Ocean and flows to low latitudes, and is considered the main transport path of nutrients from the Southern Ocean to upwelling zones of the Pacific Ocean $[115,116]$. Similarly, the AAIW forms close to Antarctica by the sinking of oxygen and nutrient-rich (especially phosphate) surface water of the Southern Ocean to depths right below the SAMW [115], and is suggested to feed temporary biological productivity at lower latitudes [117]. Recent GEOTRACES data from the southwest Atlantic show the injection of oxygenated and nutrient-rich water from the AAIW at about $700-800 \mathrm{~m}$ at $30^{\circ} \mathrm{S}$, where the Fe-Mn crusts from RGR are located. Furthermore, there is evidence that both the SAMW and the AAIW inject nutrients and trace elements like $\mathrm{PO}_{4}, \mathrm{Cd}$, and $\mathrm{Zn}[76,117,118]$ into the RGR water column between $600 \mathrm{~m}$ and $1200 \mathrm{~m}$ depths.

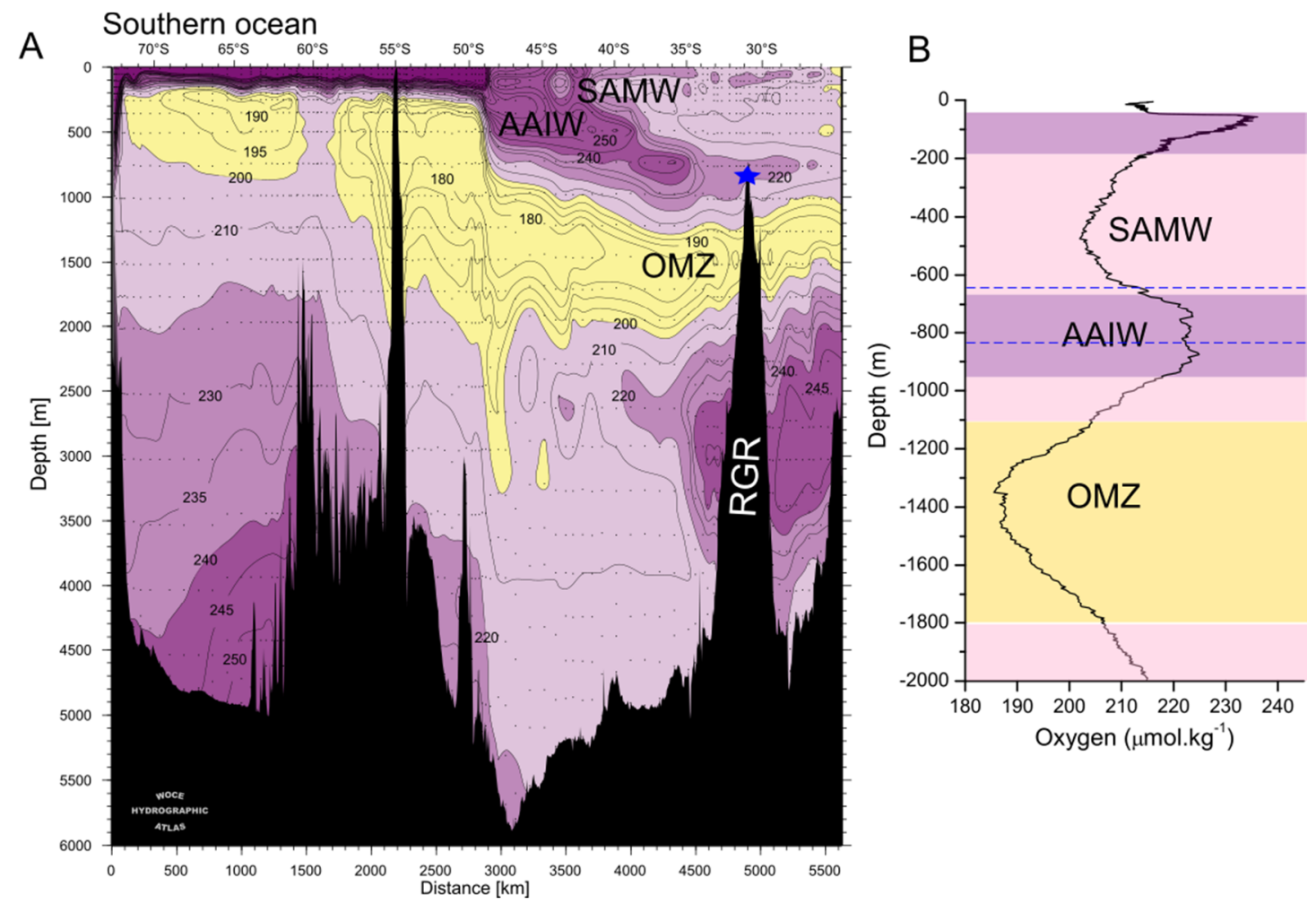

Figure 13. (A) Dissolved oxygen profile in the South Atlantic between $70^{\circ} \mathrm{S}$ and $20^{\circ} \mathrm{S}$ showing the South Atlantic Mode Water (SAMW), the Antarctic Intermediate Water (AAIW), the oxygen minimum zone (OMZ), and Rio Grande Rise (RGR) and (B) the dissolved oxygen profile at an oceanographic station at Rio Grande Rise during cruise RGR1, modified from [22]. Blue star and blue dashed lines correspond to the location and depth range of RGR crusts.

Knowledge of the export and remineralization of organic matter in the water column, an important source of dissolved metals to crusts, is scarce for waters over RGR [14]. The RGR is considered to be below the oligotrophic surface waters of the South Atlantic Subtropical regime, with relatively low primary productivity and phytoplankton biomass [119]. However, the global map of annual net primary production shows that the RGR is actually under the surface water of intermediate primary productivity, higher than in the Pacific PCZ but lower than the Northeast Atlantic, and much lower than in the central-east equatorial Pacific for example [120]. 
No investigation has been done on the possible influence of RGR itself to modify the vertical water column on a local scale. It is known that submarine topography shallower than $1000 \mathrm{~m}$ can change the water-mass structure and fertilize the euphotic zone with nutrients from underlying waters, driving enhanced primary production around the rise, or trapping and accumulating organic matter driven by secondary circulation around seamounts (e.g., [121]). It may be that instead of the global water masses providing the unique oceanographic conditions for the Fe-Mn crusts $\mathrm{c}$ at RGR, the interaction of water masses with RGR is creating a niche biological and geological environment ideal for Fe-Mn crust formation with unique locality-specific compositions.

\subsection{Resource Considerations}

Cobalt, $\mathrm{Mn}, \mathrm{Te}, \mathrm{Mo}, \mathrm{Bi}, \mathrm{Pt}, \mathrm{W}, \mathrm{Zr}, \mathrm{Nb}$, and $\mathrm{Y}$ are the critical metals of most economic interest in $\mathrm{Fe}-\mathrm{Mn}$ crusts [5]. Bulk Fe-Mn crusts from the top of the RGR plateau studied here are depleted in those metals due to phosphatization. They are, instead, the most enriched Fe-Mn crusts in Ni and Li, which are critical metals of economic interest for example in manganese nodules from the Clarion-Clipperton Zone and Peru Basin.

The younger crust generation shows that, when not affected by phosphatization, the Fe-Mn precipitates of RGR have among the highest concentrations of $\mathrm{Bi}, \mathrm{Nb}, \mathrm{Ni}, \mathrm{Te}, \mathrm{Rh}, \mathrm{Ru}$, and $\mathrm{Pt}$ among crusts from other regions. Therefore, crusts from depths deeper than $800 \mathrm{~m}$, which would less likely be affected by phosphatization, maybe more interesting from a resource point of view. Thus, further exploration is warranted to study Fe-Mn crusts from deeper water along RGR and at all depths on the summit and flanks of the seamounts that surround RGR.

The high P and F contents and CFA of RGR plateau crusts indicate that the crusts and substrate rocks in some areas might be considered as potential phosphate ores. This plateau-type phosphorite is being considered for mining offshore New Zealand on Chatham Rise and also occurs in abundance offshore of Southeast USA on Blake Plateau [49].

\section{Summary and Conclusions}

(1) Two generations of layers characterized RGR crusts: an older phosphatized generation and a younger, non-phosphatized generation. They were chemically, mineralogically, and texturally distinct, similar to crusts elsewhere in the global ocean.

(2) The younger generation was typical of hydrogenetic crusts, while the older crust generation had characteristics of diagenetic Fe-Mn deposits, such as low Fe/Mn ratios, high $\mathrm{Mn}, \mathrm{Ni}$, and Li contents and presence of $10 \AA$ manganates, all of which were likely related to the processes of phosphatization.

(3) Phosphatization affected the crust by replacing carbonates, altering the Mn-phase and partially replacing Fe oxyhydroxides. Many metals of nutrient-type distribution in the water column were likely enhanced during phosphatization.

(4) Biological productivity was an important source of metals ( $\mathrm{Ni}, \mathrm{Cd}, \mathrm{As}, \mathrm{V}$, and Li), but more importantly, was the rate at which the metals were regenerated from sinking particles in the water column.

(5) Fe-Mn crusts most likely grew at an estimated rate of about $1 \mathrm{~mm} / \mathrm{Myr}$ and may have started to form at about 48-55 Ma along the summit of Rio Grande Rise, which is younger compared to the oldest crust formation in the Pacific and Northeast Atlantic Oceans.

(6) Several episodes of phosphatization strongly affected the crusts during the Miocene, from 20 to $6.8 \mathrm{Ma}$, starting near the end of a major phosphatization event that affected many seamounts around the globe. Phosphatization was promoted by enhanced primary productivity at the shallow-water depth of formation of the crusts, between 650 and $800 \mathrm{~m}$.

(7) The Co-chronometer equations could be used to estimate the growth rates and ages of initiation of crust growth of the strongly phosphatized layers only if the growth rates are extrapolated from 
the non-phosphatized layers. Those estimated growth rates were supported by accretion rates estimated by U-series dating and constrained by Sr-isotope ages of phosphatization of the crusts. Neither method detected growth hiatuses in the crusts. Given the potential for strong currents over RGR, there might be missing stratigraphic sections in the crusts.

(8) Bulk RGR crusts were depleted in critical metals typically considered of economic interest like $\mathrm{Co}, \mathrm{REE}, \mathrm{Mo}$, and $\mathrm{Zr}$, but they were the most enriched in $\mathrm{Ni}$ and $\mathrm{Li}$, and also had high contents of the critical metals W, Rh, and Y. RGR could also be considered to host a potential phosphorite deposit like that being considered for mining on Chatham Rise offshore of New Zealand.

Supplementary Materials: The following are available online at http://www.mdpi.com/2075-163X/10/4/349/s1, Figure S1: X-ray diffraction patterns of representative crusts: a non-phosphatized Fe-Mn crust (RGR1_D02_039 L0-10) and phosphatized crusts (RGR1_D05_016 L0-23 and RGR1_D05_011 L2-10). The Mn phase $\mathrm{MnO}_{2}$ corresponds to vernadite with reflections only at $2.45 \AA\left(37^{\circ}\right)$ and $1.42 \AA$. Figure S2: XRD patterns of phosphatized Fe-Mn crusts RGR1_D02_030 L13-20, RGR1_D05_011 L2-10, and RGR1_D05_016 L0-23 before and after heating the sample at $300{ }^{\circ} \mathrm{C}$ for $24 \mathrm{~h}$. The collapse of the $10 \AA$ peak after heating is observed in all three samples. Figure S3: Plot of different metal concentrations showing the outlier sample RGR1_D10_002. Figure S4: Element enrichments/depletions for (A) mean RGR crusts and mean Atlantic Ocean crusts; (B) mean RGR crusts and mean PCZ crusts; and (C) mean RGR crusts and mean CA margin crusts. Elements above the line are enriched in the RGR crusts. Chemical composition of mean Fe-Mn crusts from the Atlantic Ocean, PCZ, and California margin from Hein et al. (2013) and Conrad et al. (2017). Table S1: Sorbed water-corrected chemical composition of ferromanganese crust samples. Table S2: Summary statistics for the chemical data. Table S3: Correlation coefficient matrix of the chemical data for non-phosphatized Fe-Mn crusts. Correlation coefficients in bold are within the $99 \%$ confidence level for $N=7$. Table S4: Correlation coefficient matrix of the chemical data for phosphatized Fe-Mn crusts. Correlation coefficients in bold are within the $99 \%$ confidence level for $N=16$. Table S5: ${ }^{87} \mathrm{Sr} /{ }^{86} \mathrm{Sr}$ isotopic ratio of purified CFA from RGR Fe-Mn crusts and ages based on the age model for the Sr isotopic composition of seawater from McArthur et al. (2012). Table S6: U-Th isotopic data for sample RGR1_D07_002. Table S7: Comparison between the chemical composition of Fe-Mn crusts from the RGR and Fe-Mn deposits from elsewhere, as compiled by Conrad et al. (2017) and Hein and Koschinsky (2014).

Author Contributions: Data curation, M.B.; Formal analysis, M.B., K.M., and T.B.; Funding acquisition, L.J.; Investigation, M.B.; Project administration, L.J.; Supervision, J.R.H. and L.J.; Writing-original draft, M.B.; Writing-review and editing, J.R.H., L.J. and K.M. All authors have read and agreed to the published version of the manuscript.

Funding: The scientific cruise RGR1 was funded by Fundação de Amparo à Pesquisa do Estado de São Paulo (FAPESP) by the research grant 14/50820-7 thematic project "Marine ferromanganese deposits: a major resource of E-tech elements".

Acknowledgments: M.B. thanks the Ph.D. scholarships from CNPq process 141918/2018-7 and FAPESP process 2018/05114-8, and the USGS Pacific Coastal and Marine Science Center in Santa Cruz CA USA for hosting while working on the manuscript. We thank the RV Alpha Crucis crew (Instituto Oceanográfico da Universidade de São Paulo, Brazil) for support during sample and data collection. We thank three anonymous reviewers that provided many helpful comments and suggestions.

Conflicts of Interest: The authors declare no conflict of interest.

\section{References}

1. Hein, J.R.; Koschinsky, A. Deep-Ocean Ferromanganese Crusts and Nodules. In Treatise on Geochemistry; Scott, S., Ed.; Elsevier: Amsterdam, The Netherlands, 2014; pp. 273-291. [CrossRef]

2. Koschinsky, A.; Hein, J.R. Marine Ferromanganese Encrustations: Archives of Changing Oceans. Elements 2017, 13, 177-182. [CrossRef]

3. Graedel, T.E.; Harper, E.M.; Nassar, N.T.; Nuss, P.; Reck, B.K.; Turner, B.L. Criticality of metals and metalloids. Proc. Natl. Acad. Sci. USA 2015, 112, 4257-4262. [CrossRef] [PubMed]

4. Clark, M.; Heydon, R.; Hein, J.; Smith, S.; Smith, C.; Petersen, S.; Baker, E.; Beaudoin, Y. Cobalt-rich Ferromanganese Crusts, A physical, biological, environmental, and technical review. Deep Sea Miner. 2013, 1C, 1-52.

5. Hein, J.R.; Mizell, K.; Koschinsky, A.; Conrad, T.A. Deep-ocean mineral deposits as a source of critical metals for high- and green-technology applications: Comparison with land-based resources. Ore Geol. Rev. 2013, 51, 1-14. [CrossRef] 
6. Hein, J.; Conrad, T.; Mizell, K.; Banakar, V.K.; Frey, F.A.; Sager, W.W. Controls on ferromanganese crust composition and reconnaissance resource potential, Ninetyeast Ridge, Indian Ocean. Deep. Res. Part I 2016, 110, 1-19. [CrossRef]

7. Hein, J.R.; Conrad, T.A.; Dunham, R.E. Seamount Characteristics and mine-site model applied to explorationand mining-lease-block selection for cobalt-rich ferromanganese crusts. Mar. Georesources Geotechnol. 2009, 27, 160-176. [CrossRef]

8. Koschinsky, A.; Van Gerven, M.; Halbach, P. First investigations of massive ferromanganese crusts in the ne atlantic in comparison with hydrogenetic pacific occurrences. Mar. Georesources Geotechnol. 1995, 13, 375-391. [CrossRef]

9. Muiños, S.B.; Hein, J.R.; Frank, M.; Monteiro, J.H.; Gaspar, L.; Conrad, T.; Pereira, H.G.; Abrantes, F. Deep-sea Fe-Mn Crusts from the Northeast Atlantic Ocean: Composition and Resource Considerations. Mar. Georesources Geotechnol. 2013, 31, 40-70. [CrossRef]

10. Conrad, T.; Hein, J.R.; Paytan, A.; Clague, D.A. Formation of Fe-Mn crusts within a continental margin environment. Ore Geol. Rev. 2017, 87, 25-40. [CrossRef]

11. Marino, E.; González, F.J.; Somoza, L.; Lunar, R.; Ortega, L.; Vázquez, J.T.; Reyes, J.; Bellido, E. Strategic and rare elements in Cretaceous-Cenozoic cobalt-rich ferromanganese crusts from seamounts in the Canary Island Seamount Province (northeastern tropical Atlantic). Ore Geol. Rev. 2017, 87, 41-61. [CrossRef]

12. Goto, K.T.; Nozaki, T.; Toyofuku, T.; Augustin, A.H.; Shimoda, G.; Chang, Q.; Kimura, J.I.; Kameo, K.; Kitazato, H.; Suzuki, K. Paleoceanographic conditions on the São Paulo Ridge, SW Atlantic Ocean, for the past 30 million years inferred from $\mathrm{Os}$ and $\mathrm{Pb}$ isotopes of a hydrogenous ferromanganese crust. Deep. Res. Part II Top. Stud. Oceanogr. 2017, 146, 82-92. [CrossRef]

13. Benites, M.; Millo, C.; Hein, J.; Nath, B.N.; Murton, B.; Galante, D.; Jovane, L. Integrated Geochemical and Morphological Data Provide Insights into the Genesis of Ferromanganese Nodules. Minerals 2018, 8, 488. [CrossRef]

14. Montserrat, F.; Guilhon, M.; Vinicius, P.; Corrêa, F.; Menezes, N.; Negrão, C.; Marone, P.; Santos, M.D.L.; Moura, D.; Jovane, L.; et al. Deep-sea mining on the Rio Grande Rise (Southwestern Atlantic): A review on environmental baseline, ecosystem services and potential impacts. Deep. Res. Part I 2019, 145, 31-58. [CrossRef]

15. Mohriak, W.U.; Nobrega, M.; Odegard, M.E.; Gomes, B.S.; Dickson, W.G. Geological and geophysical interpretation of the Rio Grande Rise, south-eastern Brazilian margin: Extensional tectonics and rifting of continental and oceanic crusts. Pet. Geosci. 2010, 16, 231-245. [CrossRef]

16. Ussami, N.; Chaves, C.A.M.; Marques, L.S.; Ernesto, M. Origin of the Rio Grande Rise-Walvis Ridge reviewed integrating palaeogeographic reconstruction, isotope geochemistry and flexural modelling. Geol. Soc. Lond. Spec. Publ. 2013, 369, 129-146. [CrossRef]

17. Camboa, L.A.P.; Rabinowitz, P.D. The evolution of the Rio Grande Rise in the southwest Atlantic Ocean. Mar. Geol. 1984, 58, 35-58. [CrossRef]

18. Emelyanov, E.M.; Trimonis, E.S. Geochemical investigation of sediments from the Brazil Basin and the Rio Grande Rise. Initial Rep. Deep Sea Drill. Proj. 1983, 72, 421-442. [CrossRef]

19. Hu, X.; Wang, Y.L.; Schmitt, R.A. Geochemistry of sediments on the Rio Grande Rise and the redox evolution of the South Atlantic Ocean. Geochim. Cosmochim. Acta 1988, 52, 201-207. [CrossRef]

20. Liu, Y.G.; Schmitt, R.A. Chemical profiles in sediments and basalt samples from Deep Sea Drilling Project Leg 74, hole 525A, Walvis Ridge. Initial Rep. DSDP 1984, 74, 713-730. [CrossRef]

21. Harlamov, V.; Lisniowski, M.; Frazão, E.; Pessoa, J.; Aguiar, R.; Lopes, V.; Nobrega, M.; Lisboa, M.; Simões, H.; Cavalacanti, J.; et al. Preliminary results onmid-depth circulation features on Rio Grande Rise. In Acoustics in Underwater Geosciences Symposium (Rio Acoustics); de Janeiro, R., Ed.; IEEE: Piscataway, NJ, USA, 2015. [CrossRef]

22. Jovane, L.; Hein, J.R.; Yeo, I.A.; Benites, M.; Bergo, N.M.; Corrêa, P.V.F.; Couto, D.M.; Guimarães, A.D.; Howarth, S.A.; Miguel, H.R.; et al. Multidisciplinary Scientific Cruise to the Rio Grande Rise. Front. Mar. Sci. 2019, 6, 1-7. [CrossRef]

23. Cook, H.E.; Johnson, P.D.; Matti, J.C.; Zemmels, I. Methods of sample preparation and X-ray Diffraction data analysis X-ray mineralogy laboratory, Deep Sea Drilling Project, University of California Riverside2. In Sedimentology, Physical Properties, and Geochemistry in the Initial Reports of the Deep Sea Drilling Project, Volumes 1-44: An Overview; University of California: Oakland, CA, USA, 1975; pp. 999-1007. 
24. Hein, J.R.; Schwab, W.C.; Davis, A.S. Cobalt- and platinum-rich ferromanganese crusts and associated substrate rocks from the Marshall Islands. Mar. Geol. 1988, 78, 255-283. [CrossRef]

25. Ruttenberg, K.C. Development of a sequential extraction method for different forms of phosphorus in marine sediments. Limnol. Oceanogr. 1992, 37, 1460-1482. [CrossRef]

26. Silverman, S.; Fuyat, R.; Weiser, J. Quantitative determination of calcite associated with carbonate-bearing apatites. Am. Mineral. 1952, 37, 211-222.

27. McLennan, S.M. Rare earth elements in sedimentary rocks; influence ofprovenance and sedimentary processes. Rev. Mineral. 1989, 21, 169-200.

28. Pisias, N.G.; Murray, R.W.; Scudder, R.P. Multivariate statistical analysis and partitioning of sedimentary geochemical data sets: General principles and specific MATLAB scripts. Geochem. Geophys. Geosyst. 2013, 14, 4015-4020. [CrossRef]

29. Manheim, F.T.; Lane-Bostwick, C.M. Cobalt in ferromanganese crusts as a monitor of hydrothermal discharge on the Pacific sea floor. Nature 1988, 335, 59-62. [CrossRef]

30. Puteanus, D.; Halbach, P. Correlation of Co concentration and growth rate-A method for age determination of ferromanganese crusts. Chem. Geol. 1988, 69, 73-85. [CrossRef]

31. Akovali, Y.A. Nuclear data sheets for A=234. Nucl. Data Sheets 1994, 71, 181-259. [CrossRef]

32. Cheng, H.; Edwards, R.L.; Hoff, J.; Gallup, C.D.; Richards, D.A.; Asmerom, Y. The half-lives of uranium-234 and thorium-230. Chem. Geol. 2000, 169, 17-33. [CrossRef]

33. Matthews, K.A.; Murrell, M.T.; Goldstein, S.J.; Nunn, A.J.; Norman, D.E. Uranium and Thorium Concentration and Isotopic Composition in Five Glass (BHVO-2G, BCR-2G, NKT-1G, T1-G, ATHO-G) and Two Powder (BHVO-2, BCR-2) Reference Materials. Geostand. Geoanal. Res. 2011, 35, 227-234. [CrossRef]

34. McArthur, J.; Howarth, R.J.; Shields, G.A. Strontium isotope stratigraphy. In The Geologic Time Scale 2012; Gradstein, F., Ogg, J.G., Schmitz, M.D., Ogg, G.M., Eds.; Elsevier: Oxford, UK, 2012; pp. 127-144. [CrossRef]

35. Kuhn, T.; Wegorzewski, A.; Rühlemann, C.; Vink, A. Composition, formation, and occurrence of polymetallic nodules. In Deep-Sea Mining; Sharma, R., Ed.; Springer International Publishing: Basel, Switzerland, 2017; pp. 23-63. [CrossRef]

36. Chukhrov, F.V. On Vernadite. Int. Geol. Rev. 1980, 22, 58-74. [CrossRef]

37. Lee, S.; Xu, H.; Xu, W.; Sun, X. The structure and crystal chemistry of vernadite in ferromanganese crusts research papers. Acta Crystallogr. 2019, B75, 591-598.

38. Bodeï, S.; Manceau, A.; Geoffroy, N.; Baronnet, A.; Buatier, M. Formation of todorokite from vernadite in Ni-rich hemipelagic sediments. Geochim. Cosmochim. Acta 2007, 71, 5698-5716. [CrossRef]

39. Varentsov, I.M.; Drits, V.A.; Gorshkov, A.I.; Sivtsov, A.V.; Sakharov, B.A. Mn-Fe oxyhydroxide crusts from Krylov Seamount (Eastern Atlantic): Mineralogy, geochemistry and genesis. Mar. Geol. 1991, 96, 53-70. [CrossRef]

40. Manceau, A.; Lanson, M.; Takahashi, Y. Mineralogy and crystal chemistry of Mn, Fe, Co, Ni, and Cu in a deep-sea Pacific polymetallic nodule. Am. Mineral. 2014, 99, 2068-2083. [CrossRef]

41. Manceau, A.; Gorshkov, A.I.; Drits, V.A. Structural chemistry of Mn, Fe, Co, and Ni in manganese hydrous oxides: Part II. Information from EXAFS spectroscopy and electron and X-ray diffraction. Am. Mineral. 1992, 77, 1144-1157.

42. Bilinski, H.; Giovanoli, R.; Usui, A.; Hanžel, D. Characterization of Mn oxides in cemented streambed crusts from Pinal Creek, Arizona U.S.A., and in hot-spring deposits from Yuno-Taki Falls, Hokkaido, Japan. Am. Mineral. 2002, 87, 580-591. [CrossRef]

43. Vereshchagin, O.S.; Perova, E.N.; Brusnitsyn, A.I.; Ershova, V.B.; Khudoley, A.K.; Shilovskikh, V.V.; Molchanova, E.V. Ferro-manganese nodules from the Kara Sea: Mineralogy, geochemistry and genesis. Ore Geol. Rev. 2019, 106, 192-204. [CrossRef]

44. Novikov, G.V.; Bogdanova, O.Y. Transformations of ore minerals in genetically different oceanic ferromanganese rocks. Lithol. Miner. Resour. 2007, 42, 303-317. [CrossRef]

45. Wegorzewski, A.V.; Kuhn, T.; Dohrmann, R.; Wirth, R.; Grangeon, S. Mineralogical characterization of individual growth structures of Mn-nodules with different $\mathrm{Ni}+\mathrm{Cu}$ content from the central Pacific Ocean. Am. Mineral. 2015, 100, 2497-2508. [CrossRef]

46. Usui, A.; Yuasa, M.; Yokota, S.; Nohara, M.; Nishimura, A.; Murakami, F. Submarine hydrothermal manganese deposits from the Ogasawara (Bonin) arc, off the Japan islands. Mar. Geol. 1986, 73, 311-322. [CrossRef]

47. Hein, J.R.; Koschinsky, A.; Halbach, P.; Manheim, F.T.; Bau, M.; Kang, J.; Lubick, N. Iron and manganese oxide mineralization in the Pacific. Manganese Miner. Geochem. Mineral. Terr. Mar. Depos. 1997, 119, $123-138$. 
48. Dasgupta, R.; Jackson, M.G.; Lee, C.T.A. Major element chemistry of ocean island basalts-Conditions of mantle melting and heterogeneity of mantle source. Earth Planet. Sci. Lett. 2010, 289, 377-392. [CrossRef]

49. Hein, J.; Koschinsky, A.; Mikesell, M.; Mizell, K.; Glenn, C.; Wood, R. Marine Phosphorites as Potential Resources for Heavy Rare Earth Elements and Yttrium. Minerals 2016, 6, 88. [CrossRef]

50. Bruland, K.W.; Middag, R.; Lohan, M.C. Controls of Trace Metals in Seawater. In Treatise on Geochemistry: Second Edition; Mottl, M.J., Elderfield, H., Eds.; Elsevier Ltd.: Philadelphia, PA, USA, 2013; Volume 8, pp. 19-51. [CrossRef]

51. Claude, C.; Suhr, G.; Hofmann, A.W.; Koschinsky, A. U-Th chronology and paleoceanographic record in a Fe-Mn crust from the NE Atlantic over the last $700 \mathrm{ka}$. Geochim. Cosmochim. Acta 2005, 69, 4845-4854. [CrossRef]

52. Josso, P.; Parkinson, I.; Horstwood, M.; Lusty, P.; Chenery, S.; Murton, B. Improving confidence in ferromanganese crust age models: A composite geochemical approach. Chem. Geol. 2019, 513, 108-119. [CrossRef]

53. Yeo, I.A.; Howarth, S.A.; Spearman, J.; Cooper, A.; Crossouard, N.; Taylor, J.; Turnbull, M.; Murton, B.J. Distribution of and hydrographic controls on ferromanganese crusts: Tropic Seamount, Atlantic. Ore Geol. Rev. 2019, 114, 103131. [CrossRef]

54. Hein, J.R.; Koschinsky, A.; Bau, M.; Manheim, F.T.; Kang, J.; Roberts, L. Cobalt-rich ferromanganese crusts in the Pacific. In Handbook of Marine Mineral Deposits; CRC Marine Science Series; Cronan, D.S., Ed.; CRC Press: Boca Raton, FL, USA, 2000; pp. 239-279.

55. Koschinsky, A.; Stascheit, I.A.; Bau, M.; Halbach, P. Effects of phosphatization on the geochemical and mineralogical composition of marine ferromanganese crusts. Geochim. Cosmochim. Acta 1997, 6, 4079-4094. [CrossRef]

56. Nishi, K.; Usui, A.; Nakasato, Y.; Yasuda, H. Formation age of the dual structure and environmental change recorded in hydrogenetic ferromanganese crusts from Northwest and Central Pacific seamounts. Ore Geol. Rev. 2017, 87, 62-70. [CrossRef]

57. Usui, A.; Nishi, K.; Sato, H.; Nakasato, Y.; Thornton, B.; Kashiwabara, T.; Tokumaru, A.; Sakaguchi, A.; Yamaoka, K.; Kato, S.; et al. Continuous growth of hydrogenetic ferromanganese crusts since $17 \mathrm{Myr}$ ago on Takuyo-Daigo Seamount, NW Pacific, at water depths of 800-5500 m. Ore Geol. Rev. 2017, 87, 71-87. [CrossRef]

58. De Carlo, E.H. Paleoceanographic implications of rare earth element variability within a FeMn crust from the central Pacific Ocean. Mar. Geol. 1991, 98, 449-467. [CrossRef]

59. McMurtry, G.M.; VonderHaar, D.L.; Eisenhauer, A.; Mahoney, J.J.; Yeh, H.W. Cenozoic accumulation history of a Pacific ferromanganese crust. Earth Planet. Sci. Lett. 1994, 125, 105-118. [CrossRef]

60. Barker, P.F. Tectonic evolution and subsidence history of the Rio Grande Rise. Initial Rep. DSDP Leg 72 Santos Brazil 1983, 953-976. [CrossRef]

61. Manheim, F.T.; Pratt, R.M.; McFarlin, P.F. Composition and Origin of Phosphorite Deposits of the Blake Plateau. In Marine Phosphorites—Geochemistry, Occurrence, Genesis; Bentor, Y.K., Ed.; SEPM Society for Sedimentary Geology: Tulsa, OK, USA, 1980; Volume 29, pp. 117-137. [CrossRef]

62. Lea, D.W. Trace elements in foraminiferal calcite. In Modern Foraminifera; Gupta, B.K.S., Ed.; Springer: Dordrecht, The Netherlands, 1999; pp. 259-277. [CrossRef]

63. Mizell, K.; Hein, J.R.; Lam, P.J.; Koppers, A.A.P.; Staudigel, H. Geographic and oceanographic influences on ferromanganese crust composition along a Pacific Ocean meridional transect, $14 \mathrm{~N}$ to $14 \mathrm{~S}$. Geochem. Geophys. Geosyst. 2019, 21. [CrossRef]

64. Cutter, G.A.; Cutter, L.S.; Featherstone, A.M.; Lohrenz, S.E. Antimony and arsenic biogeochemistry in the western Atlantic Ocean. Deep. Res. Part II Top. Stud. Oceanogr. 2001, 48, 2895-2915. [CrossRef]

65. Andreae, M.O. Arsenic speciation in seawater and interstitial waters: The influence of biological-chemical interactions on the chemistry of a trace element. Limnol. Oceanogr. 1979, 24, 440-452. [CrossRef]

66. Bertine, K.K.; Koide, M.; Goldberg, E.D. Aspects of rhodium marine chemistry. Mar. Chem. 1993, 42, $199-210$. [CrossRef]

67. Collier, R.W. Particulate and dissolved vanadium in the North Pacific Ocean. Nature 1984, 309, $441-444$. [CrossRef]

68. Heggie, D.; Kahn, D.; Fischer, K. Trace metals in metalliferous sediments, MANOP Site M: Interfacial pore water profiles. Earth Planet. Sci. Lett. 1986, 80, 106-116. [CrossRef]

69. Sohrin, Y.; Fujishima, Y.; Ueda, K.; Akiyama, S.; Mori, K.; Hasegawa, H.; Matsui, M. Dissolved niobium and tantalum in the North Pacific. Geophys. Res. Lett. 1998, 25, 999-1002. [CrossRef] 
70. Flegal, A.R.; Patterson, C.C. Vertical concentration profiles of lead in the Central Pacific at $15^{\circ} \mathrm{N}$ and $20^{\circ} \mathrm{S}$. Earth Planet. Sci. Lett. 1983, 64, 19-32. [CrossRef]

71. Lee, D.S.; Edmond, J.M. Tellurium species in seawater. Nature 1985, 313, 782-785. [CrossRef]

72. Dong Soo, L.; Edmond, J.M.; Bruland, K.W. Bismuth in the Atlantic and North Pacific: A natural analogue to plutonium and lead? Earth Planet. Sci. Lett. 1986, 76, 254-262. [CrossRef]

73. Alibo, D.S.; Nozaki, Y. Rare earth elements in seawater: Particle association, shale-normalization, and Ce oxidation. Geochim. Cosmochim. Acta 1999, 63, 363-372. [CrossRef]

74. Jacinto, G.S.; Van Den Berg, C.M.G. Different behaviour of platinum in the Indian and Pacific Oceans. Nature 1989, 338, 332-334. [CrossRef]

75. Colodner, D.C.; Boyle, E.A.; Edmond, J.M. Determination of Rhenium and Platinum in natural waters and sediments, and Iridium in sediments by flow injection isotope dilution inductively coupled plasma mass spectrometry. Anal. Chem. 1993, 65, 1419-1425. [CrossRef]

76. López-Sánchez, D.E.; Cobelo-García, A.; Rijkenberg, M.J.A.; Gerringa, L.J.A.; de Baar, H.J.W. New insights on the dissolved platinum behavior in the Atlantic Ocean. Chem. Geol. 2019, 511, 204-211. [CrossRef]

77. Banakar, V.K.; Hein, J.R.; Rajani, R.P.; Chodankar, A.R. Platinum group elements and gold in ferromanganese crusts from Afanasiy-Nikitin seamount, equatorial Indian Ocean: Sources and fractionation. J. Earth Syst. Sci. 2007, 116, 3-13. [CrossRef]

78. Baturin, G.N.; Dubinchuk, V.T. Mineralogy and Chemistry of Ferromanganese Crusts from the Atlantic Ocean. Geochemistry Int. 2011, 49, 578-593. [CrossRef]

79. Konstantinova, N.; Cherkashov, G.; Hein, J.R.; Mirão, J.; Dias, L.; Madureira, P.; Kuznetsov, V.; Maksimov, F. Composition and characteristics of the ferromanganese crusts from the western Arctic Ocean. Ore Geol. Rev. 2017, 87, 88-99. [CrossRef]

80. Glasby, G.P.; Mountain, B.; Vineesh, T.C.; Banakar, V.; Rajani, R.; Ren, X. Role of hydrology in the formation of Co-rich Mn crusts from the equatorial N pacific, equatorial S Indian ocean and the NE Atlantic ocean. Resour. Geol. 2010, 60, 165-177. [CrossRef]

81. Hein, J.; Gunn, H.; Sliter, V.; Benninger, M. Two major Cenozoic episodes of phosphogenesis recorded in Equatorial Pacific seamounts deposits. Paleoceanography 1993, 8, 293-311. [CrossRef]

82. Benninger, L.M.; Hein, J.R. Diagenetic evolution of seamount phosphorite. In Marine Authigenesis. From Global to Microbial; SEPM: Tulsa, OK, USA, 2000; pp. 245-256. [CrossRef]

83. Koschinsky, A.; Halbach, P.; Hein, J.R.; Mangini, A. Ferromanganese crusts as indicators for paleoceanographic events in the NE Atlantic. Geol. Rundschau 1996, 85, 567-576. [CrossRef]

84. Burns, V.M.; Burns, R.G. Post-depositional metal enrichment processes inside manganese nodules from the north equatorial Pacific. Earth Planet. Sci. Lett. 1978, 39, 341-348. [CrossRef]

85. Sclater, F.; Boyle, E.A.; Edmond, J.M. On the marine geochemistry of nickel. Earth Planet. Sci. Lett. 1976, 31, 119-128. [CrossRef]

86. Bruland, K.W. Oceanographic distributions of cadmium, zinc, nickel, and copper in the North Pacific. Earth Planet. Sci. Lett. 1980, 47, 176-198. [CrossRef]

87. Lohan, M.C.; Statham, P.J.; Crawford, D.W. Total dissolved zinc in the upper water column of the subarctic North East Pacific. Deep. Res. Part II Top. Stud. Oceanogr. 2002, 49, 5793-5808. [CrossRef]

88. Boyle, E.A.; Sclater, F.; Edmond, J.M. On the marine geochemistry of cadmium. Nature 1976, 263, 42-44. [CrossRef]

89. George, E.; Stirling, C.H.; Gault-Ringold, M.; Ellwood, M.J.; Middag, R. Marine biogeochemical cycling of cadmium and cadmium isotopes in the extreme nutrient-depleted subtropical gyre of the South West Pacific Ocean. Earth Planet. Sci. Lett. 2019, 514, 84-95. [CrossRef]

90. Dean, W.E.; Zheng, Y.; Ortiz, J.D.; van Geen, A. Sediment Cd and Mo accumulation in the oxygen-minimum zone off western Baja California linked to global climate over the past 52 kyr. Paleoceanography 2006, 21, 1-13. [CrossRef]

91. Horner, T.J.; Schonbachler, M.; Rehkamper, M.; Nielsen, S.G.; Williams, H.; Halliday, A.N.; Xue, Z.; Hein, J.R. Ferromanganese crusts as archives of deep water Cd isotope compositions. Geochem. Geophys. Geosyst. 2010, 11, 1-10. [CrossRef]

92. Calvert, S.E. Deposition and diagenesis of silica in marine sediments. In Pelagic sediments: On land and under the sea; Hsu, K.J., Jenkyns, H.C., Eds.; International Association of Sedimentologists Series: Oxford, UK, 1974; Volume 1, pp. 273-299. 
93. Murray, R.W.; Leinen, M.; Isern, A.R. Biogenic flux of Al to sediment in the Central Equatorial Pacific Ocean: Evidence for increased productivity during glacial periods. Paleoceanography 1993, 8, 651-670. [CrossRef]

94. Jiang, X.; Lin, X.; Yao, D.; Zhai, S.; Guo, W. Geochemistry of lithium in marine ferromanganese oxide deposits. Deep. Res. Part I Oceanogr. Res. Pap. 2007, 54, 85-98. [CrossRef]

95. Manheim, F.T.; Gulbrandsen, R.A. Marine phosphorites. In Marine Minerals; Burns, R.G., Ed.; Mineralogical Society of America: Chantilly, VA, USA, 1979; pp. 151-173.

96. Jiang, X.-D.; Sun, X.-M.; Chou, Y.-M.; Hein, J.R.; He, G.-W.; Fu, Y.; Li, D.; Liao, J.-L.; Ren, J.-B. Mineralogy and geochemistry of carbonate fluorapatite in seamount Fe Mn crusts from the Pacific Ocean. Mar. Geol. 2020, 423, 106135. [CrossRef]

97. De Baar, H.J.W.; Bacon, M.P.; Brewer, P.G.; Bruland, K.W. Rare earth elements in the Pacific and Atlantic Oceans. Geochim. Cosmochim. Acta 1985, 49, 1943-1959. [CrossRef]

98. Zhang, J.; Nozaki, Y. Rare earth elements and yttrium in seawater: ICP-MS determinations in the East Caroline, Coral Sea, and South Fiji basins of the western South Pacific Ocean. Geochim. Cosmochim. Acta 1996, 60, 4631-4644. [CrossRef]

99. Hein, J.R.; Conrad, T.A.; Frank, M.; Christl, M.; Sager, W.W. Copper-nickel-rich, amalgamated ferromanganese crust-nodule deposits from Shatsky Rise, NW Pacific. Geochem. Geophys. Geosyst. 2012, 13, 1-23. [CrossRef]

100. Delaney, M.L.; Boyle, E.A. Lithium in foraminiferal shells: Implications for high-temperature hydrothermal circulation fluxes and oceanic crustal generation rates. Earth Planet. Sci. Lett. 1986, 80, 91-105. [CrossRef]

101. Bau, M.; Schmidt, K.; Koschinsky, A.; Hein, J.; Kuhn, T.; Usui, A. Discriminating between different genetic types of marine ferro-manganese crusts and nodules based on rare earth elements and yttrium. Chem. Geol. 2014, 381, 1-9. [CrossRef]

102. Bau, M.; Koschinsky, A.; Dulski, P.; Hein, J.R. Comparison of the partitioning behaviours of yttrium, rare earth elements, and titanium between hydrogenetic marine ferromanganese crusts and seawater. Geochim. Cosmochim. Acta 1996, 60, 1709-1725. [CrossRef]

103. Baturin, G.N.; Yushina, I.G. Rare earth elements in phosphate-ferromanganese crusts on Pacific seamounts. Lithol. Miner. Resour. 2007, 42, 101-117. [CrossRef]

104. Klinkhammer, G.P.; Elderfield, H.; Edmond, J.M.; Mitra, A. Geochemical implications of rare earth element patterns in hydrothermal fluids from mid-ocean ridges. Geochim. Cosmochim. Acta 1994, 58, 5105-5113. [CrossRef]

105. Alt, J.C. Hydrothermal oxide and nontronite deposits on seamounts in the eastern Pacific. Mar. Geol. 1988, 81, 227-239. [CrossRef]

106. Hein, J.R.; Hsueh-Wen, Y.; Gunn, S.H.; Gibbs, A.E.; Chung-ho, W. Composition and origin of hydrothermal ironstones from central Pacific seamounts. Geochim. Cosmochim. Acta 1994, 58, 179-189. [CrossRef]

107. Hein, J.R.; Conrad, T.A.; Staudigel,H. Seamount minerals deposits: A source of rare metals for high-technology industries. Oceanography 2010, 23, 184-189. [CrossRef]

108. Josso, P.; Pelleter, E.; Pourret, O.; Fouquet, Y.; Etoubleau, J.; Cheron, S.; Bollinger, C. A New Discrimination Scheme for Oceanic Ferromanganese Deposits using High Field Strength and Rare Earth Elements. Ore Geol. Rev. 2017, 87, 3-15. [CrossRef]

109. Hyeong, K.; Kim, J.; Yoo, C.M.; Moon, J.W.; Seo, I. Cenozoic history of phosphogenesis recorded in the ferromanganese crusts of central and western Pacific seamounts: Implications for deepwater circulation and phosphorus budgets. Palaeogeogr. Palaeoclimatol. Palaeoecol. 2013, 392, 293-301. [CrossRef]

110. Keigwin, L.D.; Corliss, B.H. Stable isotopes in late middle Eocene to Oligocene foraminifera. Geol. Soc. Am. Bull. 1986, 97, 335-345. [CrossRef]

111. Florindo, F.; Gennari, R.; Persico, D.; Turco, E.; Villa, G.; Lurcock, P.C.; Roberts, A.P.; Winkler, A.; Carter, L.; Pekar, S.F. New magnetobiostratigraphic chronology and paleoceanographic changes across the OligoceneMiocene boundary at DSDP Site 516 (Rio Grande Rise, SW Atlantic). Paleoceanography 2015, 30, 659-681. [CrossRef]

112. Levitan, M.A.; Strizhov, V.P.; Schevtchenko, A.Y. Cherts from Rio Grande Rise sediments, Deep Sea Drilling Project leg 72, hole 516F. Initial Rep. DSDP 2007. [CrossRef]

113. Jones, E.J.W.; Boudagher-Fadel, M.K.; Thirlwall, M.F. An investigation of seamount phosphorites in the eastern Equatorial Atlantic. Mar. Geol. 2002, 183, 143-162. [CrossRef]

114. Berggren, W.A.; Aubry, M.P.; Hamilton, N. Neogene magnetobiostratigraphy of Deep Sea Drilling Project Site 516 (Rio Grande Rise, South Atlantic). Initial Rep. DSDP 1983, 72, 675-713. [CrossRef] 
115. Sarmiento, J.L.; Gruber, N.; Brzezinski, M.A.; Dunne, J.P. High-latitude controls of thermocline nutrients and low latitude biological productivity. Nature 2004, 427, 56-60. [CrossRef] [PubMed]

116. Ayers, J.M.; Strutton, P.G. Nutrient variability in Subantarctic Mode Waters forced by the Southern Annular Mode and ENSO. Geophys. Res. Lett. 2013, 40, 3419-3423. [CrossRef]

117. Poggemann, D.W.; Hathorne, E.C.; Nürnberg, D.; Frank, M.; Bruhn, I.; Reißig, S.; Bahr, A. Rapid deglacial injection of nutrients into the tropical Atlantic via Antarctic Intermediate Water. Earth Planet. Sci. Lett. 2017, 463, 118-126. [CrossRef]

118. Middag, R.; de Baar, H.J.W.; Bruland, K.W. The relationships between dissolved zinc and major nutrients phosphate and silicate along the GEOTRACES GA02 transect in the West Atlantic Ocean. Glob. Biogeochem. Cycles 2019, 33, 63-84. [CrossRef]

119. Perez, J.A.A.; Alves, E.S.; Clark, M.R.; Bergstad, O.A.; Gebruk, A.; Cardoso, I.A.; Rogacheva, A. Patterns of life on the Southern Mid-Atlantic Ridge: Compiling what is known and adressing future research. Oceanography 2012, 25, 16-31. [CrossRef]

120. Behrenfeld, M.J.; Falkowski, P.G. Photosynthetic rates derived from satellite-based chlorophyll concentration. Limnol. Oceanogr. 1997, 42, 1-20. [CrossRef]

121. Vilas, J.C.; Arístegui, J.; Kiriakoulakis, K.; Wolff, G.A.; Espino, M.; Polo, I.; Montero, M.F.; Mendonça, A. Seamounts and organic matter-Is there an effect? The case of Sedlo and Seine Seamounts: Part 1. Distributions of dissolved and particulate organic matter. Deep. Res. Part II 2009, 56, 2618-2630. [CrossRef]

(C) 2020 by the authors. Licensee MDPI, Basel, Switzerland. This article is an open access article distributed under the terms and conditions of the Creative Commons Attribution (CC BY) license (http://creativecommons.org/licenses/by/4.0/). 